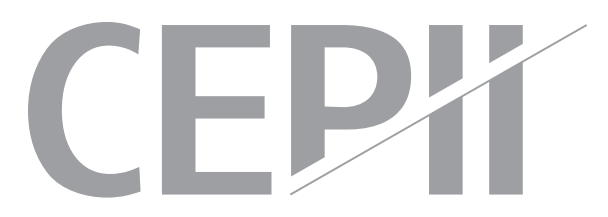

\title{
International Trade, Quality Sorting and Trade Costs: The Case of Cognac
}

Charlotte Emlinger \& Viola Lamani

Highlights

- The paper uses an original dataset of French Cognac export by quality designations.

- We investigate to what extent distance and customs duties impact the Cognac quality mix.

- We assess the impact of a variation in trade costs, through containerization, on the quality mix of Cognac exports.

- Our results confirm the Alchian and Allen effect. 


\section{Abstract}

This paper tests empirically the validity of the Alchian and Allen effect, using an original dataset of French Cognac exports by quality designations. More specifically we estimate the impact of trade costs on the share and relative price of high quality Cognac. The definition of quality, based on the minimum time in oak of the youngest eau-de-vie used in creating the blend, is subject to regulations and is constant and objective, which makes the case of Cognac particularly relevant to analyze the impact of different trade costs on the quality mix. Our estimation proceeds in two parts. First, we investigate to what extent distance and customs duties impact the Cognac quality mix from 1996 to 2013. Second, we assess the impact of a variation in trade costs, through the adoption of containerization, on the quality mix of Cognac exports between 1969 and 2013. Our results confirm the Alchian and Allen effect. We show that: (i) per-unit trade costs increase the share of high-quality Cognac and have the opposite impact on its relative price; (ii) ad-valorem charges impact negatively the share of high-quality Cognac and have a positive impact on its relative price.

\section{Keywords}

Quality Mix, Luxury Product, Distance, Tariffs.

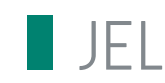

F10, F13, F14.

\section{Working Paper}

\section{CEPI}

CEPII (Centre d'Etudes Prospectives et d'Informations Internationales) is a French institute dedicated to producing independent, policyoriented economic research helpful to understand the international economic environment and challenges in the areas of trade policy, competitiveness, macroeconomics, international finance and growth
CEPII Working Paper

Contributing to research in international economics

C C CEPII, PARIS, 2017

All rights reserved. Opinions expressed in this publication are those of the author(s) alone.

$\begin{array}{ll}\text { Editorial Director: } & \text { CEPII } \\ \text { Sébastien Jean } & \begin{array}{l}113, \text { rue de Grenelle } \\ 75007 \text { Paris }\end{array} \\ \text { Production: } & +33153685500 \\ \text { Laure Boivin } & \text { www.cepii.fr } \\ \text { No ISSN: } 1293-2574 & \text { Press contact: presse@ }\end{array}$




\title{
International Trade, Quality Sorting and Trade Costs: The Case of Cognac ${ }^{1}$
}

\author{
Charlotte Emlinger* and Viola Lamani ${ }^{\dagger}$
}

\section{Introduction}

It is well known since the seminal works of Falvey (1979), Krugman (1979) and Lancaster (1980) that international trade flows are not only composed of different products, but also of similar products either horizontally or vertically differentiated. The latter type of trade is based on an objective product differentiation, where a good is considered qualitatively superior to another and recognized as such by all consumers. While trade liberalization policies have contributed to the intensification of these trade flows, trade costs continue to play an important role as determinants of the volumes and quality of traded goods. The impact of trade costs, whether natural (i.e. transportation costs) or policy-related (i.e. tariffs), on the quality structure of international trade flows has been examined extensively by both theoretical and empirical studies.

In this respect, a key pillar in the theoretical literature, yet less documented empirically, is the Alchian and Allen effect. This effect, first highlighted by Alchian and Allen in 1964, stipulates that per-unit transportation costs increase the relative demand for higher quality goods. This point gave rise to several theoretical analyzes (Borcherding and Silberberg, 1978; Razzolini, Shughart II, and Tollison, 2003; Bauman, 2004; Baldwin and Harrigan, 2011; Sorensen, 2014; Irarrazabal, Moxnes, and Opromolla, 2015), but to seldom empirical verifications. The main challenge of empirical analyzes of the Alchian and Allen effect resides in having or rather lacking an objective definition of product quality.

In this paper, we have overcome this challenge by examining Cognac export flows, a product whose definition of quality is objective and constant over time. The definition of Cognac quality is based on the minimum time in oak of the youngest eau-de-vie used in creating the blend. This ageing system and indications are closely supervised by the Cognac inter-profession (the Bureau National Interprofessionnel du Cognac, BNIC). As a consequence, the definition of quality for this product is objective and constant, contrary to the definitions of product quality of other empirical analyzes of the quality mix in the literature, which use indirect measures of product quality such as the difference observed in the unit values for a given category (see for example

\footnotetext{
${ }^{1}$ The authors are very grateful to participants in a GREThA seminar (March 9, 2017) and a CEPII seminar (May 4) for their helpful comments and suggestions. We would also like to thank Daniel Bernhofen for his suggestions at the beginning of this research project. All errors are ours.

*CEPII, (charlotte.emlinger@cepii.fr).

†GREThA, University of Bordeaux. Corresponding author. (viola.lamani@u-bordeaux.fr).
} 
Hummels and Skiba 2004, Schott 2004) or ratings from experts or guidebooks (see for example Crozet, Head and Mayer 2012, for champagne).

Our objective is to test the validity of the Alchian and Allen effect using a unique database of Cognac exports by volume, destination and quality from 1967 to 2013 and a database on customs protection. We do so by exploiting both the cross-sectional and time-series dimensions of trade costs. More specifically, we first estimate the impact of the cross-sectional variation of trade costs through distance and tariffs. Second, we evaluate the impact of a reduction in trade costs over time as a result of the technological revolution in maritime transport following the adoption of containerization.

Our work contributes to the literature on trade costs and their impact on product quality. As we said above, despite distinguished theoretical studies, empirical work on the subject remains relatively scarce. Moreover, the majority of papers studying the effects of trade costs estimate the impact of transportation charges (usually distance) and/or customs duties on unit values, using either country-level data (Schott 2004, 2008, Hummels and Klenow 2005, Baldwin and Harrigan 2011) or firm-level data (Bastos and Silva 2010, Manova and Zhang 2011, Martin 2012). Instead of using unit values to define a product's quality, in this paper, we estimate the impact of distance and customs duties on the quality mix of Cognac exports based on an objective definition of quality. All Cognac houses comply with such a definition, under the supervision of the BNIC.

Our paper also relates to the literature on luxury goods. Indeed, Cognac is a luxury product, based on Fogarty's (2010) estimations of the income-elasticity of demand for spirits. Moreover, important Cognac Houses, e.g. Martell and Rémy Martin, belong to the famous list of the Comité Colbert, an association of 75 French luxury brands, founded in 1954 by Jean-Jacques Guerlain to promote the concept of luxury. Among the different papers on trade of luxury goods, Fontagné and Hatte (2013) estimate a gravity equation of high-end products and find that exports of these products are less sensitive to distance and more sensitive to the Gross Domestic Product (GDP) of destination countries than other products. For their part, Martin and Mayneris (2016) conclude that high-end variety exporters are mainly characterized by more distant markets on average, and that this goes hand-in-hand with a wider geographic diversification of their exports.

This study is also related to the literature on the economic impact of containerization. The adoption of containerization (i.e. the method of shipping goods via containers) revolutionized shipping methods in the 20th century. According to Hummels (2007), it is one of the major postwar technological changes in ocean transport. The use of containers in different modes of transport, ship, rail or truck, made possible for goods to be shipped to distant destinations without the necessity of "being unpacked and repacked" (Hummels 2007, p.141). The overall quality of transportation improved, productivity of dock labor increased, and insurance costs dropped. Intermodal transport also reduced the speed of delivery. Trade and transport facilitation as a 
result of the introduction of containerization has been well documented in the literature ${ }^{2}$, but only a few studies quantify empirically the effects of the shipping container. ${ }^{3}$ To the extent of our knoweledge, we are the first to analyze empirically the impact of containerization on trade flows by quality. Using Rua (2014)'s and Bernhofen, El-Sahli and Kneller (2016)'s data on the first port containerized by country, we empirically assess the effects of the variation in trade costs as a result of containerization on the quality mix of Cognac exports.

The contribution of this article is threefold. First, we validate empirically the Alchian and Allen effect based on a direct and physical rather than perceived definition of product quality, during a long time-span covering almost forty-seven years of Cognac export flows. Second, we assess empirically the impact of customs protection on trade flows by quality by distinguishing between per-unit and ad-valorem tariffs. Third, our results confirm the Alchian and Allen effect when analyzing the time variation of trade costs through containerization.

The paper is organized as follows. First, we review the theoretical and empirical literature on the Alchian and Allen theorem. Section 3 presents our original database of Cognac exports and gives details on the different quality designations. In a fourth section, we perform an econometric estimation on the share and relative price of high quality Cognac exports to different countries. In section 5 we test empirically the impact of containerization on the Cognac quality mix. Finally in section 6 we conclude.

\section{The Alchian and Allen Effect}

In this section we first present the Alchian and Allen effect. Then we discuss several extensions to the original theoretical framework. Finally, we review the empirical examinations of the Alchian and Allen conjecture.

\subsection{Theoretical Framework}

What came to be known as the Alchian and Allen effect or the "shipping the good apples out" theorem, originally presented in their University Economics book in 1964, was considered by the two authors as an indirect validation of the laws of demand, a solution to the problem of: "...how does one explain the larger proportion of good quality relative to poor quality oranges or grapes sold in New York than in California? Why is a larger proportion of the good, rather than bad, shipped to New York?" (p.70-71 of the 1972 edition). Alchian and Allen (1964) answer this question arguing that the relative price of the high quality to the poor quality good is lower to more distant markets, therefore the relative consumption of the high quality good is greater at more distant markets compared to the market of origin.

\footnotetext{
${ }^{2}$ See for example Levinson (2006).

${ }^{3}$ See for example Bernhofen, El-Sahli and Kneller (2016) for an empirical assessment of the impact of containerization on world trade flows.
} 
For a better understanding of the effect, consider a competitive sector in country $i$ that exports two quality grades of the same good denoted by $k=H, L$ for high and low quality respectively. Note that this model can be extended to a three and/or n-good world. ${ }^{4}$

We focus on the quality mix exported to different countries and suppose that supply is fixed in the country of origin. ${ }^{5}$ For each quality grade, consider the following Hicksian demand functions (i.e. income held constant) at destination country $j: 6$

$$
X_{j k}=f\left(p_{j H}, p_{j L}, U\right), \quad k=H, L
$$

$p_{j H}, p_{j L}$ are the prices of the high and low quality good respectively at country $j$, with $p_{j H}>p_{j L}$. $U$ is the utility level.

Prices at destination country $j$ depend on prices at origin country $p_{i H}, p_{i L}$ and a per-unit charge (typically a per-unit transport cost and/or a specific duty) denoted by $t_{j}$, such as:

$$
p_{j k}=p_{i k}+t_{j}, \quad k=H, L
$$

We suppose that there is no loss in quality due to shipment. It is important to note, as pointed out by Borcherding and Silberberg (2004) that: "there must be one measurable characteristic common to both [qualities], to which the transport cost (or other common change) is applied" (p.134). Indeed, for the analysis to hold, consumers at destination country $j$ must perceive the high and low quality as two grades of the same good, rather than two different goods. The high and low quality grades must be substitutes. ${ }^{7}$

The Alchian and Allen theorem can be stated: An increase in the per-unit cost increases the relative price of the higher compared to the lower quality good leading to an increase in the quantity share of the higher quality good.

Mathematically: ${ }^{8}$

$$
\frac{\partial\left(X_{j H} / X_{j L}\right)}{\partial t_{j}}>0
$$

\footnotetext{
${ }^{4}$ See for example Borcherding and Silberberg (1978) and Bauman (2004).

${ }^{5}$ See Hummels and Skiba (2004).

${ }^{6} \mathrm{~A}$ Hicksian or compensated demand function minimizes a consumer's expenditure while the utility or income level is held constant. Borcherding and Silberberg (1978) justify the use of compensated demand curves in their theoretical development of the Alchian and Allen model by "...income effects are always indeterminate and if strong enough, can destroy this or virtually any other proposition in economics" (p.134). The use of Hicksian demand functions is also explained in Hummels and Skiba (2004).

${ }^{7}$ As Hummels and Skiba (2004) point out: "The Alchian-Allen conjecture is primarily a statement about substitution effects" (p.1388).

${ }^{8} \mathrm{~A}$ detailed proof of equation 1 is provided in the Appendix A.
} 
We test empirically the Alchian and Allen conjecture stated above in sections 4 and 5 . Because we do not have data on freight rates, we use distance as a proxy instead. In the case of Cognac, shipping fees resemble per-unit rather than iceberg charges as it is the case for wine and Champagne. ${ }^{9}$ The ad-valorem component is however still present in freight rates as insurance costs for example are more likely to depend on the price of Cognac. If we assume that the perunit charge increases more with distance than the ad-valorem one as in Crozet, Head and Mayer (2012), we expect a positive relation between distance and the relative consumption of higherquality Cognac. Specific duties are expected to have the same impact. As for containerization, we provide evidence in section 5 of a reduction of per-unit charges as a result of this technological change. We therefore expect that entering the age of containerization has the opposite impact compared to distance on the relative consumption of $\mathrm{XO}$ Cognac.

We review several extensions to the original framework in the following subsection.

\subsection{Extensions}

The theoretical literature following the work of Alchian and Allen is quite large. Here we review some of the theoretical examinations more closely related to our work.

Borcherding and Silberberg (1978) extend the original Alchian and Allen conjecture by building a theoretical model in a three-good world with two close-substitutes qualities of the same good and a third composite (i.e. Hicksian) good. They show that the theorem holds under the plausible condition that the elasticities of substitution/complementarity between the two quality differentiable goods and the composite good are similar. ${ }^{1011}$

The validity of the theorem is questioned by Razzolini, Shughart II and Tollison (2003) when taking into account the supply side. Under an increasing cost-industry or a monopolistic market structure, it is shown that a per-unit charge would reduce the relative price of the higher quality good if the price-elasticity of the lower quality good is less or at most equal to the price elasticity of the higher quality good. The condition for the Alchian and Allen proposition to hold is considered therefore implausible from an empirical point of view.

Another extension of the model is proposed by Hummels and Skiba (2004). While their paper's main contribution is in providing empirical evidence of the Alchian and Allen effect (see section 2.3), their work also relates to the theoretical literature. The authors consider the effect on the relative prices and demand of both per-unit and ad-valorem charges. They show that an increase in the ad-valorem charges (in presence of per-unit transportation costs) would increase

\footnotetext{
${ }^{9}$ See Crozet, Head and Mayer (2012).

${ }^{10}$ The authors argue that "we should be surprised if the cross elasticities of Golden Delicious and McIntosh apples with other goods differ widely". (p.135)

${ }^{11}$ An extension of the Borcherding and Silberberg (1978) analysis to a n-good world is developed by Bauman (2004).
} 
the relative price of the higher-quality good, invalidating therefore the Alchian and Allen effect. ${ }^{12}$ Given the data on ad-valorem duties at our disposal we are also able to test in section 4 the validity of the extension to the original framework developed by Hummels and Skiba (2004).

The majority of the theoretical analyzes have focused on two quality grades of the same good with the exception of Liu (2010). ${ }^{13}$ The author builds a model with consumers purchasing a bundle of low, medium and high quality grades of a given good where the quality of the bundle depends on the shares of medium and high quality grades. Under several assumptions on consumers' demand functions, Liu (2010) demonstrates that a per-unit increase in the prices of the three qualities in the bundle, leads to an increase in the quality of the bundle, extending therefore the Alchian and Allen effect to three quality-differentiable goods. ${ }^{14}$

\subsection{Empirical Verification}

Despite the extensive theoretical literature, the empirical verifications of the Alchian and Allen conjecture are relatively scarce. One of the major difficulties comes from the definition of quality. In the vaster literature regarding the quality mix, we distinguish between three definitions of quality : (I) based on unit values ${ }^{15}$ (II) extrapolated from an econometric estimation ${ }^{16}$, and finally (III) based on ratings from experts or guidebooks ${ }^{17}$.

Hummels and Skiba (2004) are to our knowledge the first to validate empirically the Alchian and Allen theorem ${ }^{18}$. Using bilateral trade data on six importers and worldwide exporters for 1994 , they first estimate the price-elasticity of transportation costs and then proceed in evaluating the impact of freight rates and ad-valorem duties on the average unit prices of more than 5000 products. In contrast to standard trade theory where transportation costs are considered to have an iceberg form (proportional to the value of the good), the authors find that the price-elasticity of freight rates is 0,6 and conclude that shipping fees have a per-unit rather than per-value structure. ${ }^{19}$ Lacking a direct measure of quality, the authors consider the unit value by product to be a weighted average of prices for each quality within product and interpret an increase (decrease) of such value as an increase (decrease) in the share of the high quality goods. Their theoretical predictions are confirmed (see section 2.2) since their results show that freight rates

\footnotetext{
${ }^{12}$ Considering that transportation charges may have both a per-unit and ad-valorem components, the authors also argue that the validity of the Alchian and Allen effect depends on the price-elasticity of transportation costs.

${ }^{13}$ A previous working paper by Saito (2006) also explores the validity of the Alchian and Allen proposition for various qualities.

${ }^{14}$ Other theoretical analyzes of the Alchian and Allen effect are developed by Gould and Segall (1969), Umbeck (1980), Kaempfer and Brastow (1985).

${ }^{15}$ See for example Hummels and Skiba (2004), Schott (2004).

${ }^{16}$ See for example Khandelwal, Schott and Wei (2013).

17 See for example Crozet, Head and Mayer (2012).

${ }^{18}$ A previous study by Bertonazzi, Maloney and McCormick (1993) provides empirical evidence of the validity Alchian and Allen proposition in the case of consumers being shipped to goods.

${ }^{19}$ Otherwise the price-elasticity of freight rates would be equal to 1 . They also find that freight rates increase with distance while the cost per unit decreases with units shipped.
} 
have a significant positive impact on the average unit value, while ad-valorem duties have the opposite effect.

Lawson and Raymer (2006) offer an empirical analysis of the gasoline market distinguishing between three quality grades of gasoline: regular, mid and premium grade. Using daily observations of gasoline sales at a single station from 1992 to 1999, their study reveals that the market share of premium grade gasoline decreased by 1.4 percentage point in response to an increase of ten cents of the average prices. They find therefore no evidence of the Alchian and Allen effect and conclude that: "these results are simply inconsistent with the expectations of the model" (p.3). Another study focusing on the gasoline market is Nesbit (2007). Contrary to his predecessors, the author finds a negative (positive) and significant effect of unit taxes on regular (premium) market shares of gasoline using state-level daily data on gasoline sales from 1991 to $2001 .^{20}$

Finally, Crozet, Head and Mayer (2012) develop a Melitz (2003)-type model and study the Champagne market. They use experts (Parker 2002' and Juhlin 2008's) ratings to distinguish between different qualities of Champagne. On the impact of distance and the Alchian and Allen effect, they conclude that "Alchian-Allen effects are not entirely absent, but they have little impact on the main finding: higher quality generally increases FOB prices and export values over all distances." (p. 630-631).

\section{Cognac Quality Designations}

In this section we explain the definition of the different Cognac qualities and present a unique dataset of Cognac exports from 1967 to 2013. As stated in the introduction, Cognac makes a compelling case for testing empirically the impact of trade costs and the Alchian and Allen conjecture given that the definition of quality is objective and constant over time.

\subsection{Qualities Depending on the Ageing System}

The definition of the different qualities of Cognac depends on the production and ageing system which are subject to regulations and are closely supervised by the BNIC. We have therefore a direct measure of product quality, a "physical" quality which is different than perceived quality. More precisely, the classification in a given designation is based on the minimum time in oak of the youngest eau-de-vie used in creating the blend. ${ }^{21}$ Cognac VS (for Very Special) is the lowest quality of Cognac: the minimum time in oak legally required by the youngest eau-devie in creating a VS cognac is two years. Cognac VSOP (for Very Superior Old Pale) is the medium quality of Cognac: the minimum time in oak legally required by the youngest eau-de-vie in creating a VSOP cognac is four years. Cognac XO (for Extra Old) is the highest quality of

\footnotetext{
${ }^{20}$ Nesbit (2007)'s contribution is more relevant as an empirical validation of Barzel (1976)'s tax theory.

${ }^{21}$ Unlike wine, Cognac does not mature in bottle.
} 
Cognac: the minimum time in oak legally required by the youngest eau-de-vie in creating a $\mathrm{XO}$ cognac is six years (see figure 1 ). ${ }^{22}$ The ageing system and indications are adopted by all the Maisons de Cognac. The quality of the different designations are reflected in the French market prices, as Cognac VS prices range from 25 to 45 euros per bottle, Cognac VSOP from 32 to 57 euros per bottle and finally Cognac XO from 45 to 94 euros per bottle in $2015 .{ }^{23}$

\section{Figure 1 - Definition of Cognac Qualities}

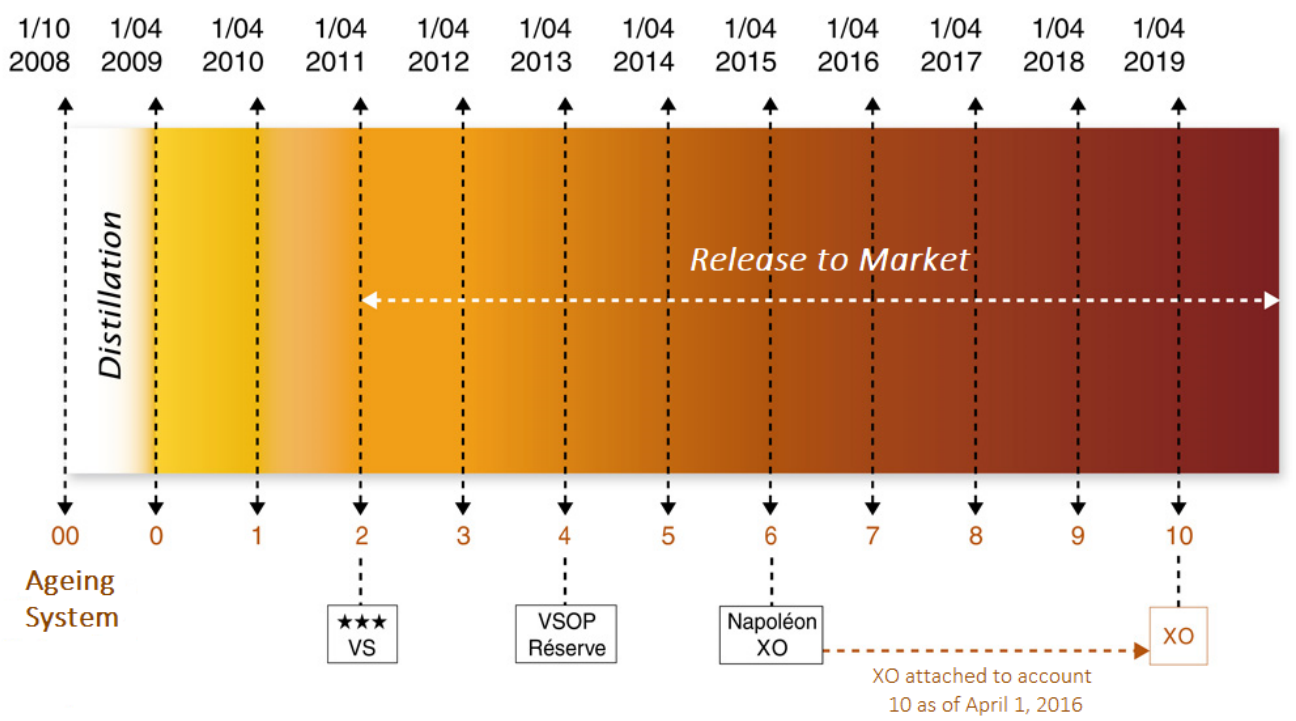

Source: BNIC (authors' translation in English).

\subsection{An Original Dataset}

We build a unique database of Cognac exports based on raw data of shipments in volume and value terms by year, destination and quality designations provided by the BNIC. ${ }^{24}$ Our database covers a 47 year-long period of time from 1967 to 2013 with information on more than 160 countries. ${ }^{25}$

\footnotetext{
${ }^{22}$ The quality designations VS, VSOP, XO to be used based on the age of the Cognac in the blend were codified by a decision of the Government Commissioner to the BNIC in 1983. The raw data on Cognac exports at our disposal between 1967-1987 were classified only by the Cognac age. For this time period we associated quality designations to the corresponding Cognac age based on the aforementioned definitions.

${ }^{23}$ All these figures are from Sud-Ouest - April 11, 2015. Some bottles of Cognac are much more expensive. The price of a bottle of Cognac Hennessy Paradis was 924 euros on February 2015 on the website LaCognatheque. On the same website you could buy at the same date a bottle of Richard Hennessy for 2780 euros. Paradis is made of eau-de-vie of at least 25 years (40 years in the case of a bottle of Richard Hennessy).

${ }^{24}$ We are grateful to the BNIC for helping us from the start with the constitution of this database, as well as for the constant attention and the interesting suggestions addressed to our work. In particular we thank Janine Bretagne, Christakis Christodoulou, Stéphane Feuillet, Sébastien Freulon, Lionel Lalague and Catherine Lepage.

${ }^{25}$ Details on the compilation of these data may be requested from the authors.
} 
Figure 2 shows the Kernel distribution of the log of unit values by quality designations for 2013. Our objective is to see if the three objective Cognac quality definitions are indeed perceived as different qualities by foreign consumers based on their price differences. The highest Cognac quality has distinctly a larger price range and is more expensive than VS and VSOP. The VS unit price is lower and more concentrated. While VSOP's price is in the mid-range segment, it is closer to the lower than higher quality Cognac.

Figure 2 - Kernel Density of Export Unit Values (in Log) by Quality Designations, 2013

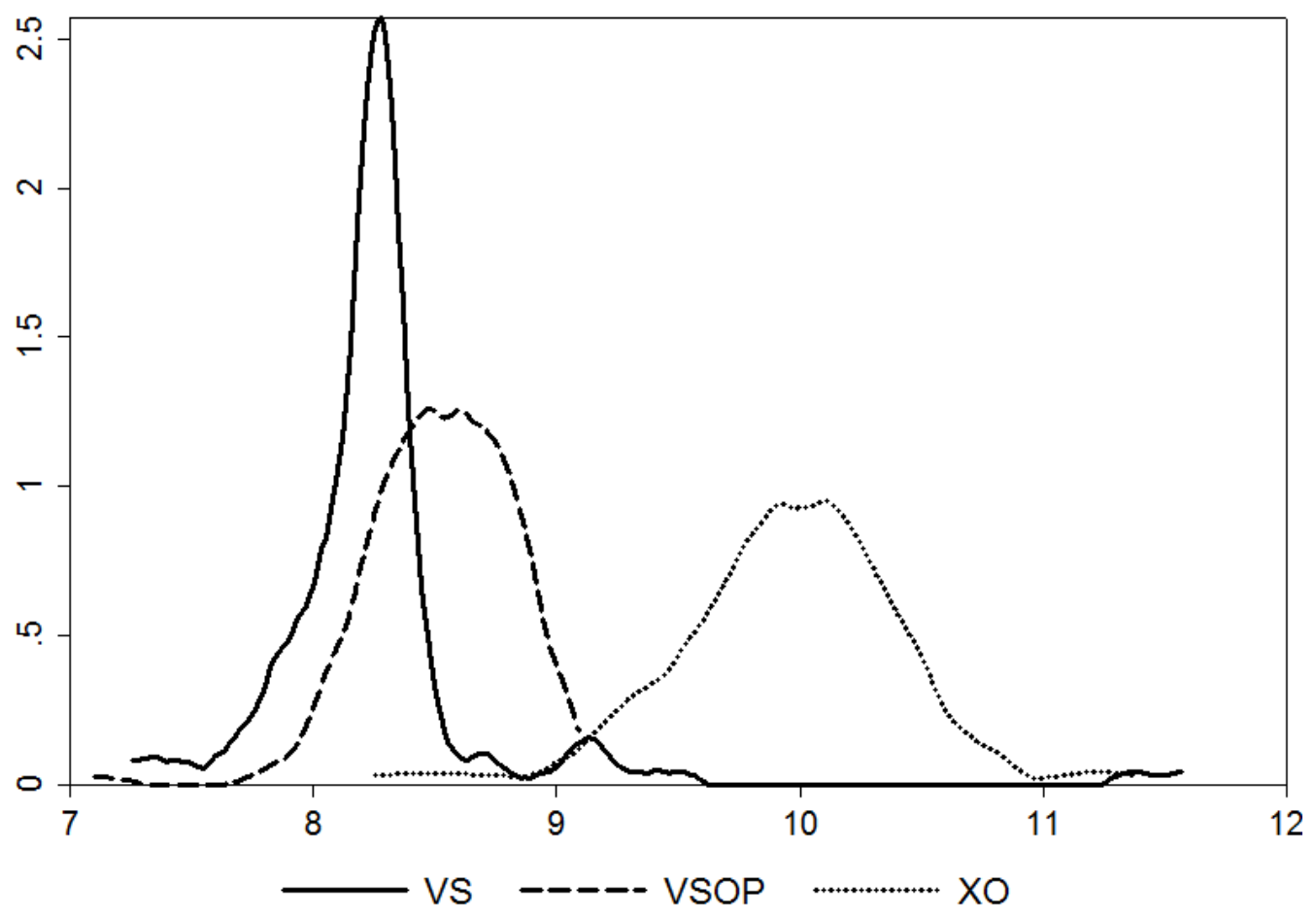

Figure 3 shows the evolution of the quality mix of French Cognac exports to all destinations for 1967-2013. While the low quality Cognac has always dominated total shipments in terms of volume, its relative importance has decreased from $76 \%$ in 1967 to $44 \%$ of total exports in 2013. VSOP Cognac shares have on the other hand more than quadrupled during the same period of time, from $10 \%$ to $42 \%$ of total exports. The highest quality Cognac exports have increased in volume terms but their relative importance was the same in 2013 compared to $1967,14 \%$ of total exports.

In the following sections, we use this original dataset of Cognac exports to analyze the impact of trade cost on the Cognac quality mix, first focusing on the impact of distance and tariffs, and second exploiting time variations in transportation costs, through containerization. 
Figure 3 - Evolution of Cognac Exports by Quality Designations, 1967-2013

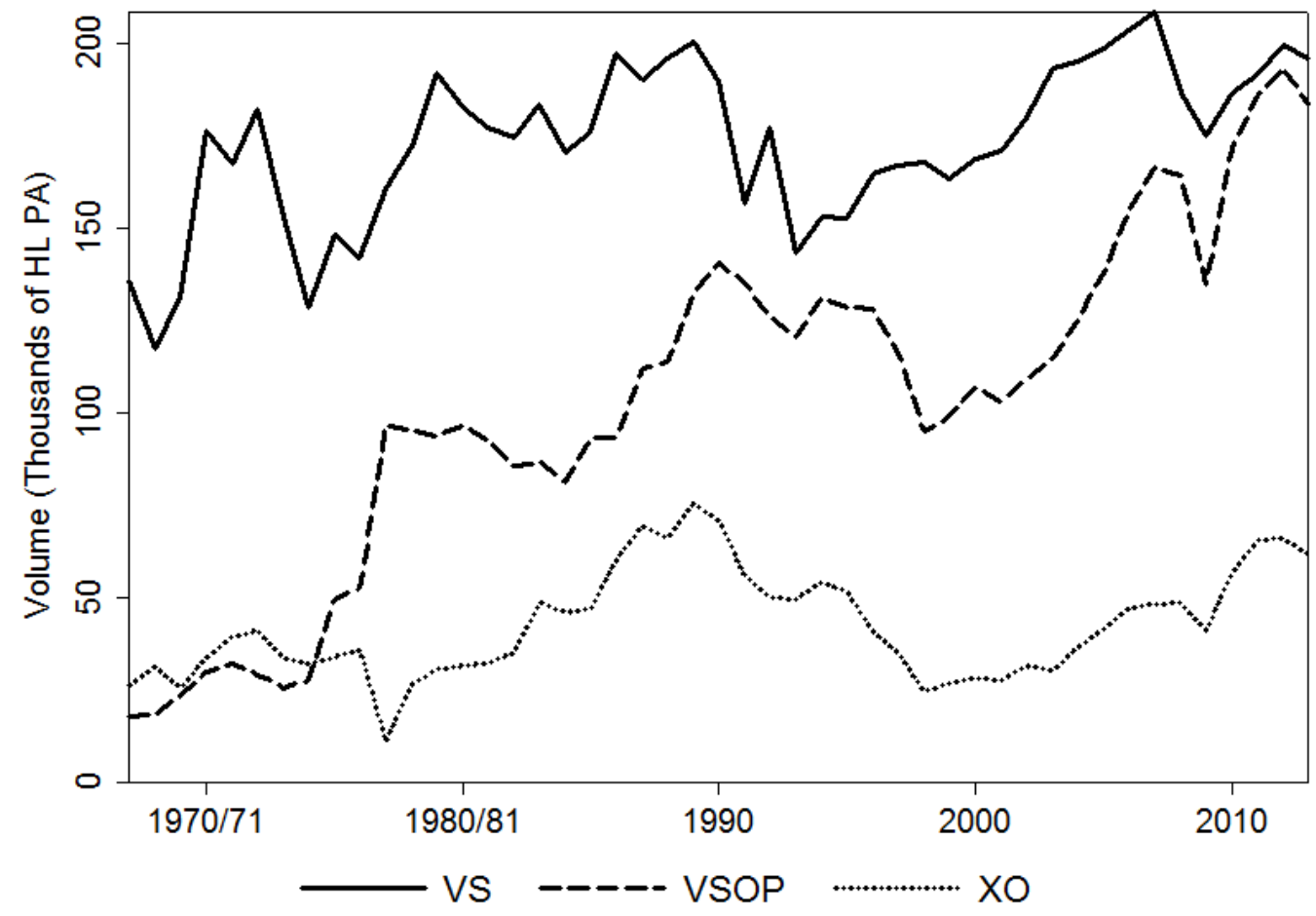

\section{Distance, Tariffs and Quality Mix}

In this section, we assess the determinants of the quality mix of French exports of Cognac. We study in particular to what extent trade costs (distance, ad-valorem and specific duties), impact the share and the relative price of high quality Cognac in the destination country.

\subsection{Stylized Facts}

Figure 4 shows the share of the highest $(\mathrm{XO})$ quality of Cognac in countries' imports in 2013. The quality mix appears to vary among countries. High quality $(\mathrm{XO})$ accounts for more than a third of Cognac imports in some distant Asian countries as China and Hong Kong. European and American countries on the other hand, exhibit the opposite pattern, importing therefore higher shares of low and medium quality Cognac. ${ }^{26}$.

To go further, figure 5 plots the share of the highest quality in imports of various countries in 2013, according to their distance to France. It shows an increasing relationship between the XO share in a country's imports and its distance from France. This stylized fact seems to confirm the Alchian and Allen conjecture, stating that transport costs increase the relative demand for more expensive/higher quality goods.

\footnotetext{
${ }^{26}$ See details for the main markets for $\mathrm{XO}$ in Table B.1 in the Appendix B
} 
Figure 4 - Share of XO in Cognac's Imports in 2013

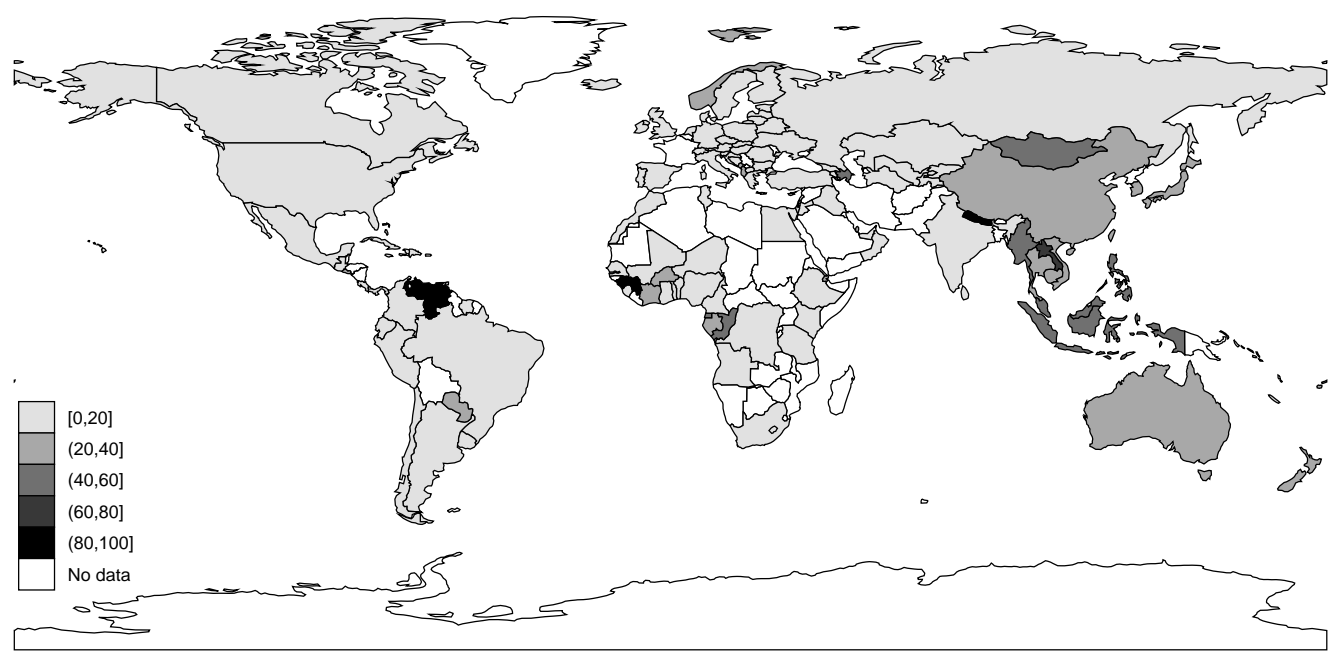

Figure 5 - Share of XO in Imports according to Distance

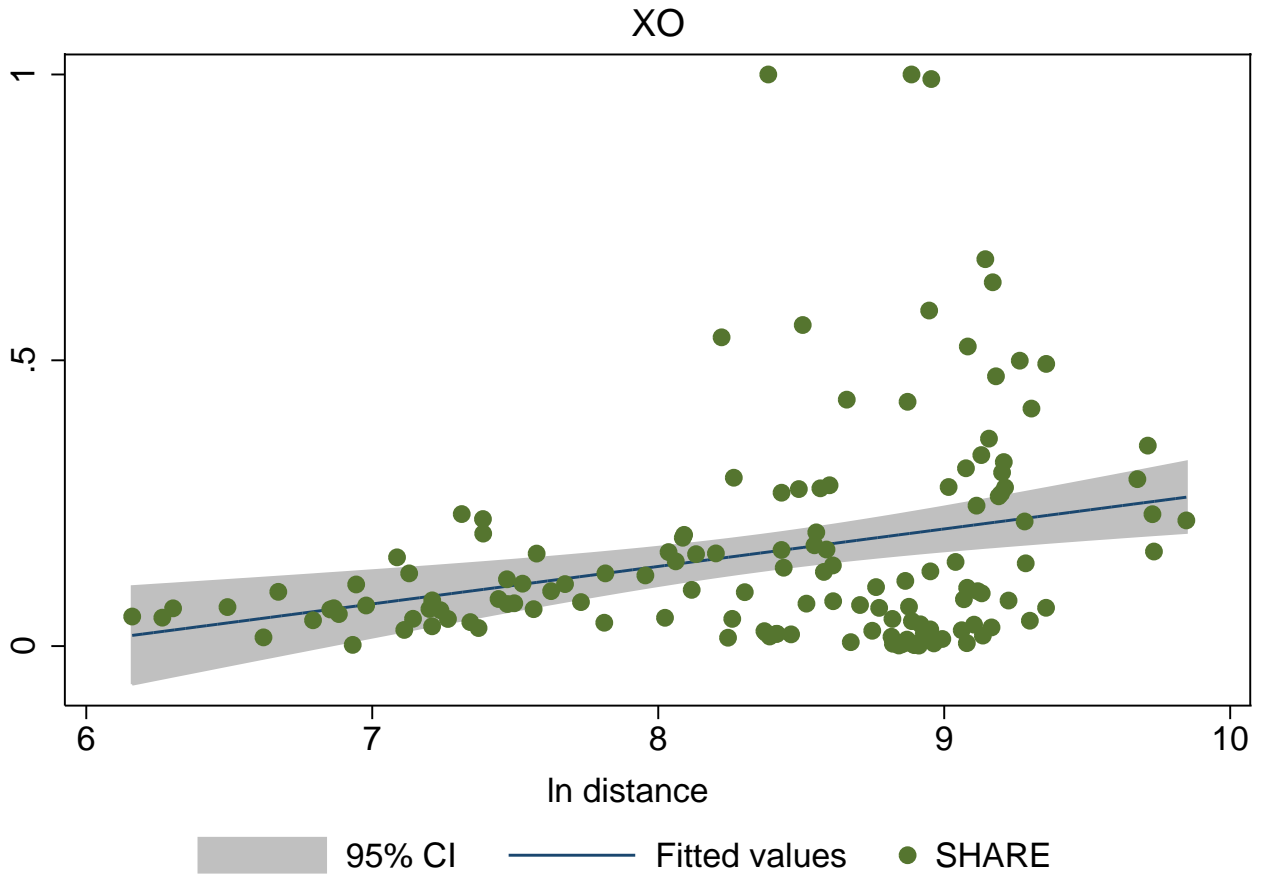




\subsection{Empirical Strategy and Data}

To test the predictions of the Alchian and Allen conjecture, we investigate the determinants of the share of high quality $(\mathrm{XO})$ Cognac and its relative price in the country of destination.

The equation we estimate is the following:

$$
\begin{aligned}
X_{j t}= & \alpha_{1} \ln G D P_{j t}+\alpha_{2} \ln G D P / c a p_{j t}+\alpha_{3} \ln d i s t_{j}+\alpha_{4} \ln E X R a t e_{j t} \\
& +\alpha_{5} \ln a d v_{j t}+\alpha_{6} \ln s p e_{j t}+\nu_{t}+u_{j t}
\end{aligned}
$$

$X_{j t}$ is our dependent variable: (i) the share of $X O$ in Cognac export to country $j$ the year $t$ in volume and (ii) the price of $X O$ exported to country $j$ the year $t$, relative to the mean price of the three qualities in $j$ at time t. GDP $P_{j t}$ and $G D P / c a p_{j t}$ are respectively the GDP and the GDP per Capita of country $j$ at year $t$, dist $t_{j}$ the distance from France to country $j$, ExRate R $_{j t}$ the nominal exchange rate of country $j$ 's currency vis-a-vis the Euro at year $t . a d v_{j t}$ and $s p e_{j t}$ are ad-valorem (defined in percentage) and specific duties (defined in monetary units by units of volume), implemented by country $j$ at year $t .{ }^{27}$ Finally, time fixed effects are included to control for the supply side.

Data on each country j's GDP and GDP per capita are in constant 2005 US dollars and were retrieved from the World Bank World Development Indicators Databank. Nominal exchange rates are annual averages of daily observations from fxtop.com and we use CEPIl's weighted bilateral distance measure. We use information on ad-valorem and specific duties on an annual basis from the International Trade Centre (ITC). ${ }^{28}$ Our customs protection database covers more than 140 importing countries from 1996 to $2013 .{ }^{29}$

Equation 2 is estimated using OLS over the period from 1996 to 2013, because tariffs data are not available before 1996. We only keep in our panel countries that import all three qualities of Cognac at a given year. We purposefully restrict our panel in order to comply with one of the assumptions of the Alchian and Allen proposition that all qualities be consumed at destination country. ${ }^{30}$ We also exclude from our panel "small island" countries that exhibit a pattern in tariffs data that might bias our results. ${ }^{31}$

\footnotetext{
${ }^{27}$ We take the power of the ad-valorem and specific duties, i.e. $\left(1+a d v_{j t}\right)$ and $\left(1+s p e_{j t}\right)$ respectively.

${ }^{28}$ Special thanks to Xavier Pichot from the ITC.

${ }^{29}$ Customs duties data at our disposal are implemented on spirits obtained by distilling grape wine or grape marc (HS6 220820). Further details on the construction of this database can be found in Bouët, Emlinger and Lamani, 2017.

${ }^{30}$ Including the dropped observations (121) does not alter significantly our results.

${ }^{31}$ The excluded countries are the following: American Oceania, Andorra, Anguilla, Antigua and Barbuda, Aruba, Bahamas, Barbados, Belize, Cayman Islands, Djibouti, Fiji, Gibraltar, Grenada, Guyana, Macao, New Caledonia, Netherlands Antilles, Northern Mariana Islands, Saint Barthélemy, Saint Kitts and Nevis, Saint Lucia, Saint Vincent and the Grenadines, San Marino, Seychelles, Trinidad and Tobago, Turks and Caicos Islands, Vanuatu, British Virgin Islands, U.S. Virgin Islands.
} 


\subsection{Results}

Table 1 reports our baseline estimate of equation 2 on the share of $X O$ in Cognac exports. ${ }^{32}$ The first column of Table 1 shows the estimation of equation 2 without customs protection data. The distance exhibits a positive coefficient, meaning that France exports a higher proportion of high quality varieties to remote destinations, due to transport cost. This outcome is in line with the predictions of the Alchian and Allen theorem. The result remains unchanged when we include tariffs and total per-capita Cognac imports in columns (2) and (3).

Specific tariffs have a positive impact on the quality mix (column 2). This result also confirms the Alchian and Allen effect as per-unit duties, same as distance, increase the share of exports of high-quality Cognac. This result is robust to the inclusion of the total per-capita Cognac imports in column (3). The coefficient of the ad-valorem duties on the other hand is nonsignificant. In line with the findings of Hummels and Skiba (2004), we could expect a negative effect of ad-valorem duties on the share of $\mathrm{XO}$ Cognac exports. We find no evidence of such an effect. Our finding could be explained considering the nature of Cognac as a luxury product. Examining the quality mix of a luxury product becomes therefore more complex than what the original theoretical model and its extensions predicted (see sections 2.1 and 2.2). It is therefore not implausible that ad-valorem duties have a nonsignificant impact on the share of $\mathrm{XO}$ exports. ${ }^{33}$

In columns (4) and (5), we propose two robustness checks of our baseline estimation by excluding countries with a high level of Cognac re-exportation (Hong Kong, the Netherlands, Panama, Singapore and United Arab Emirates) ${ }^{34}$ or main importing countries (USA, China and Japan). Our results remain unchanged.

In all specifications, the GDP of country $j$ appears to have an insignificant impact on the share of $\mathrm{XO}$, while the coefficient of the per-capita GDP is positive and significant. The latter result seems to confirm Linder's (1961) theory and Hallak's (2006) empirical findings that rich countries have a preference for imports of higher-quality goods.

The estimated coefficient of the exchange rate is positive. The appreciation of the Euro increases the share of $\mathrm{XO}$ in Cognac exports. This result suggests a Veblen effect in the case of Cognac's highest quality. The demand for this product increases with its price, due to the appreciation of the Euro. ${ }^{35}$

\footnotetext{
${ }^{32}$ We "lump" VS and VSOP together and present only the estimation results for the share of XO exports, because the low and mid qualities' price ranges diverge more when compared to the $\mathrm{XO}$ unit price range than to each other (see section 3.2 and Figure 2 for more details).

${ }^{33}$ Bouët et al. (2017) show that Cognac export flows are less sensitive to distance compared to other goods and even other luxury goods. Moreover, our estimated coefficient of the per-unit duties is relatively small: 0,01 .

${ }^{34}$ The list of re-exporting countries is provided by the BNIC.

${ }^{35}$ While this variable plays an important role as a determinant of Cognac exports, we believe that Cognac Houses' management of the exchange rate risk and its volatility is quite complex and goes beyond the scope of the present analysis.
} 
So far our results confirm the predictions of the Alchian and Allen conjecture as to the impact of distance and per-unit duties on the the share of high quality Cognac in total exports. We now estimate the equation 2 on the relative price of $X O$ (high quality) to test the predictions on the relative prices. Table 2 follows exactly the same specifications as Table 1 , but with $U V_{j t}$ the price of the quality $X O$ relative to the mean price of the three qualities as dependent variable. The results are consistent with those on the share of high qualities. The relative price of high quality cognac $(\mathrm{XO})$ decreases with the distance, while distance increases its share on the destination market. This result is robust to several specifications (see columns (3) to (5)). We find a similar impact for specific duties. ${ }^{36}$ These findings support the predictions of the Alchian and Allen model on relative prices. Ad-valorem duties' estimated coefficient on the other hand is nonsignificant.

The estimated coefficient of the GDP is negative and significant. The per-capita GDP has a less robust effect, that depends on the specifications. The effect of the exchange rate on the relative export price of $\mathrm{XO}$ Cognac is consistent with our findings on the $\mathrm{XO}$ share.

In Table C.2 we perform another robustness check, using an alternative estimation method: the Pseudo-Poisson-Maximum Likelihood (PPML) method. Columns (1) and (2) report the results on the share of $\mathrm{XO}$ exports and their relative export prices respectively. Our findings are qualitatively similar to those presented in Tables 1 and 2.

\section{Containerization and Quality Mix}

Until now we have studied the impact of trade costs across countries, we now take interest in the effect of trade costs within countries. To do so, in this last empirical section, we exploit variation over time in transport costs using the historical episode of the containerization of maritime transport and investigate its impact on the quality mix of Cognac exports.

\subsection{Stylized Facts on Containerization}

Maritime transport has played a key role in Cognac history starting as early as the birth of the product itself and later on with the establishment of regular trade links between the French region and northern Europe in the $18^{\text {th }}$ century. ${ }^{37}$ Ever since, Cognac has been and continues to be an export product. Major changes to the maritime shipping methods and overall transport technology such as the introduction of containerization in the $20^{\text {th }}$ are unlikely to have left unaffected the international trade of Cognac.

Containerization is the method of shipping goods via containers. First introduced in the United

\footnotetext{
${ }^{36}$ With the exception of columns (3) and (4) of Table 2: the estimated coefficient of per-unit duties becomes in-significant.

${ }^{37}$ Cognac was first shipped in barrels. It has been shipped in bottles from the $19^{\text {th }}$ century onward.
} 
States in the second half of the $1950 \mathrm{~s}^{38}$, containerization revolutionized transportation in the $20^{\text {th }}$ century. According to Bernhofen, El-Sahli and Kneller (2016) (p.39):

"From a transportation technology perspective, containerization resulted in the introduction of intermodal freight transport, since the shipment of a container can use multiple modes of transportation - ship, rail or truck - without any handling of the freight when changing modes. By eliminating sometimes as many as a dozen separate handlings of the cargo, the container resulted in linking the producer directly to the customer."

The overall quality of transport services improved and expenses decreased as a result of the introduction of containerization. We are interested in studying its impact and the resulting variation in trade costs on the Cognac quality mix.

Containerization is responsible for a reduction in the total costs of shipment from producers to customers through different channels: improvement of dock labor productivity, increase of shipment sizes, reduction of cargo damage and pilferage, decrease in the duration of travel journeys etc. It is however difficult to quantify the impact of containerization on port-to-port freight costs. There is nevertheless evidence brought forward by Bernhofen et al. (2016) based on McKinsey (1972)'s work regarding resource savings as a result of the adoption of containerization between 1965 and 1970/1971. ${ }^{39}$ In this respect, the authors point out that insurance costs for a journey between Australia and Europe dropped from "an average of 24 pennies per ton to 4 pennies per ton" (p.39). Moreover, as a result of a significant reduction in the duration of travel journeys (from 70 to 34 days between the two continents), the "capital cost of inventory" decreased from 2 pounds per ton to 1 pound per ton (p.39).

This evidence points toward a reduction of the per-unit trade costs as a result of countries entering the age of containerization. We expect therefore this technological change to have the opposite impact of distance on the Cognac quality mix, namely a negative effect on the share of higher-quality Cognac and a positive effect on its relative price.

As we have stated previously, it is difficult to exactly quantify the impact of containerization on freight costs. It is also highly likely that containerization led not only to a decrease of perunit trade costs but also of ad-valorem charges. Unfortunately we do not have data on their magnitude. However, based on the information we display, we believe to be plausible that the reduction of per-unit trade costs as a result of containerization was relatively bigger than the reduction in the ad-valorem charges.

Using Rua (2014)'s data on the years of adoption of containerization by country (i.e. when the first port was containerized), figure 6 shows that the majority of Cognac importing countries adopted containerization in the mid 1970s and beginning of the 1980s. ${ }^{40}$ The United States was

\footnotetext{
${ }^{38}$ For a detailed description and empirical analysis of the determinants of the diffusion of containerization see Rua (2014).

${ }^{39}$ For further details, see Table 1, page 39 in Bernhofel et al. (2016).

${ }^{40} \mathrm{~A}$ complete list of Cognac importing countries and their containerization dates is provided in the Appendix D.
} 
the first country to adopt containerization in 1956, while France's first port was containerized in 1968. Among the most recent adopters are: Cambodia (2003), Vietnam (2000), Cuba (2000).

\section{Figure 6 - Number of Cognac Importing Countries by Containerization Date}

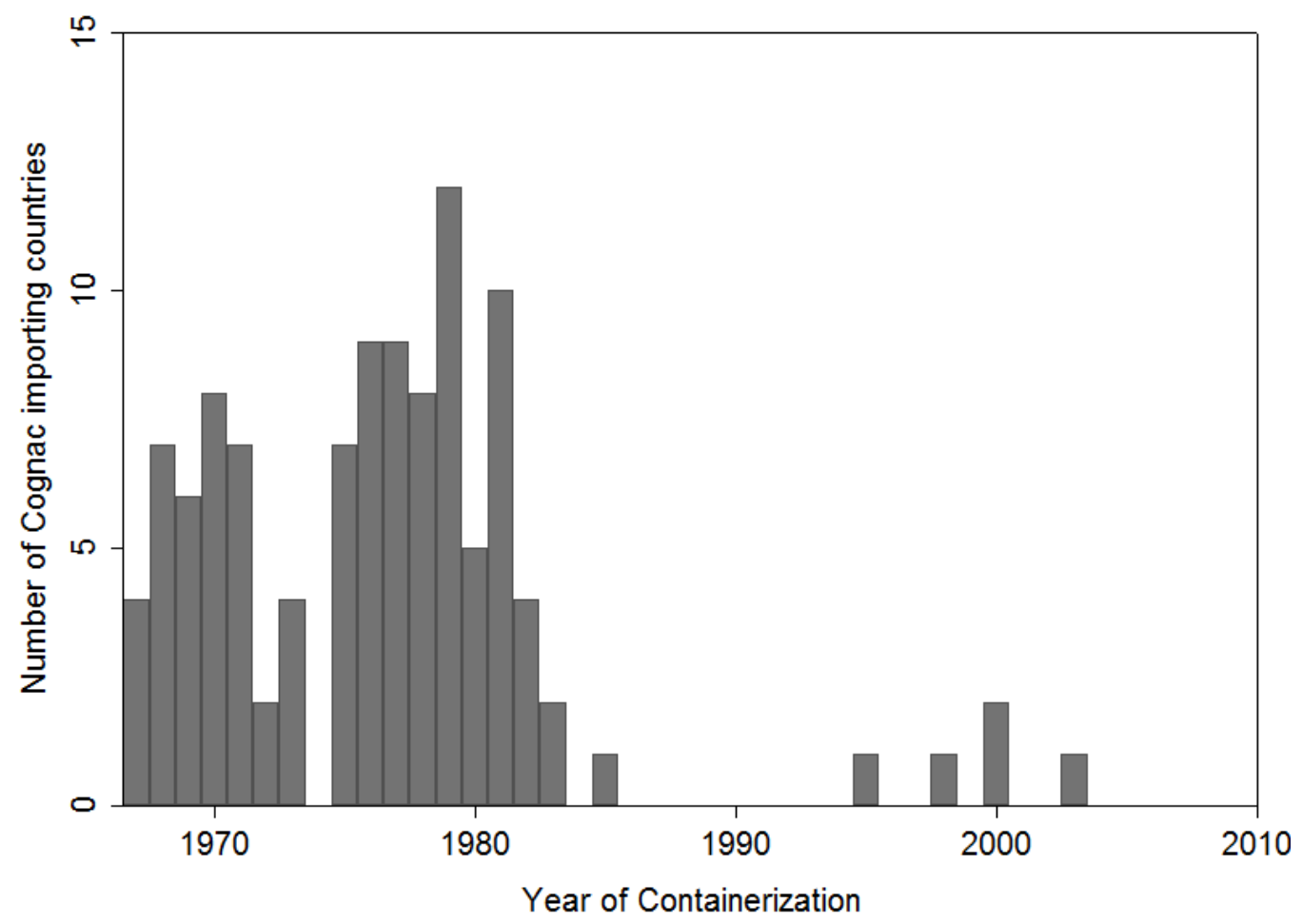

In order to see if there is indeed a difference in the share of $X O$ Cognac in total exports after containerization as a result of a decrease in trade costs, we have a first glance at the data in figure 7 . We show the evolution of the average share of exports of higher-quality Cognac during a 5 -year period before and after the containerization. There seems to be a negative relation between the share of $\mathrm{XO}$ in Cognac exports and the post-containerization period. This would confirm the Alchian and Allen conjecture. We empirically assess this effect in the next section.

\subsection{Empirical Strategy and Data}

Despite extensive literature on transportation economics acknowledging the change and improvement in shipping methods brought by containerization ${ }^{41}$, there are seldom empirical studies quantifying this effect and fewer regarding the impact of containerization on the trade of goods. The only to our knowledge is Bernhofen et al. (2016) who estimate the impact of containerization during 1962-1990 and find that containerization is associated with statistically significant and larger bilateral trade whether between North-North countries or worldwide trade.

We are grateful to Daniel Bernhofen for providing us with the data on containerization dates.

${ }^{41}$ See for example Levinson (2006). 
Figure 7 - Share of XO Exports Before and After Containerization

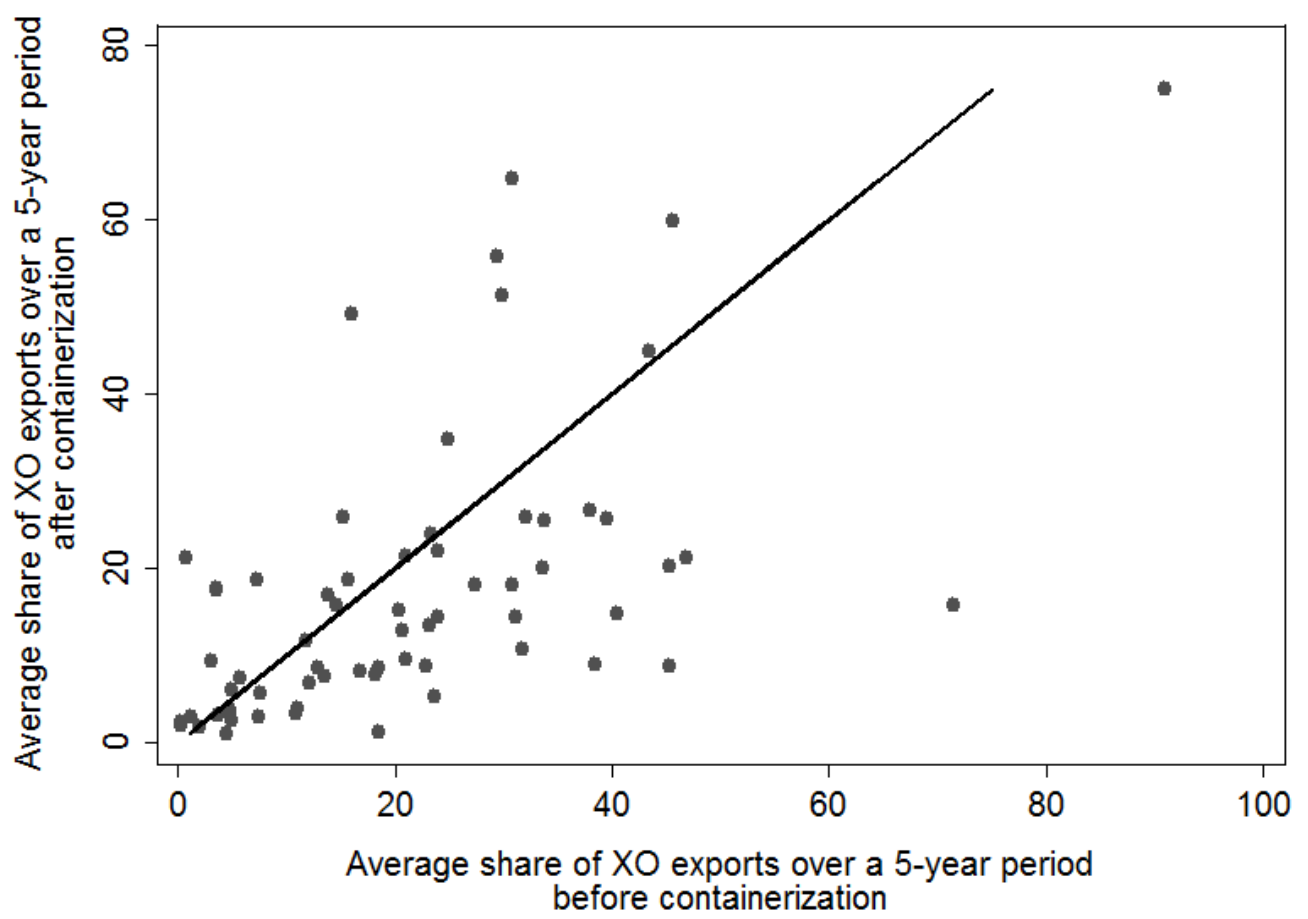

Following the same empirical strategy as in section 5, we test the Alchian and Allen conjecture by investigating the impact of the reduction of trade costs as a result of the adoption of containerization on the $\mathrm{XO}$ share and its relative price in the country of destination.

We estimate the following equation:

$$
\begin{aligned}
Y_{j t}=\beta_{1} \ln G D P_{j t} & +\beta_{2} \ln G D P / \text { cap }_{j t}+\beta_{3} \ln E \times \text { Rate }_{j t}+\beta_{4} \text { Container }_{j t}+\beta_{5} \text { After }_{j t} \\
& +\nu_{t}+\nu_{j}+u_{j, t}
\end{aligned}
$$

$Y_{j t}$ is our dependent variable: (i) the share of $X O$ in Cognac export to country $j$ the year $t$ in volume and (ii) the price of $\mathrm{XO}$ exported to country $j$ the year $t$, relative to the mean price of the three qualities in $j$ at time $t$. Container ${ }_{j t}$ is a dummy equal to 1 if country $j$ adopted containerization at year $t, 0$ otherwise. After ${ }_{j t}$ is a dummy equal to 1 if country $j$ adopted containerization at least 1 year before $t, 0$ otherwise. $\nu_{t}$ and $\nu_{j}$ are time and country fixed effects respectively. ${ }^{42}$

Note that we distinguish between the adoption date and subsequent years because containerization involved initially major changes in port facilities to accommodate this technological ad-

\footnotetext{
${ }^{42}$ Data on customs protection are available from 1996 to 2013, therefore we do not include the $A V E_{j t}$ variable when estimating equation 3.
} 
vancement. Therefore, we do not expect the impact of containerization to be visible since the first year of the adoption.

We use Rua (2014)'s data on the dates when the first ports by destination countries were containerized to construct the containerization dummies. The rest of the independent variables sources are the same to those explained in section 5 .

Equation 3 is estimated for the 1969-2013 period using OLS. ${ }^{43}$ As stated in section 4, we only keep in our panel countries that import all three qualities of Cognac at a given year.

\subsection{Results}

Table 3 presents the results of our baseline equation 3 on the share of $X O$ Cognac in exports. In the first column, the year of the adoption of containerization by the first port in the destination

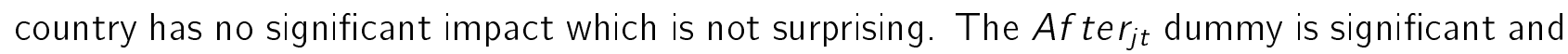
negative. Our predictions are therefore confirmed. The reduction in trade costs as a result of the adoption of containerization impacts negatively the share of the higher-quality Cognac.

As we only have data on the year of containerization by the first port in destination countries, in columns (2) and (3) we desegregate the After ${ }_{j t}$ dummy in order to capture more precisely after how many years the adoption of containerization has an impact.

We find a negative and significant effect on the shares of $\mathrm{XO}$ three years after the containerization of the first port and onward. This result is robust when we add the per-capita Cognac consumption at destination countries as a control (column 3). These results confirm our expectations and provide further empirical evidence of the Alchian and Allen proposition.

The market size does not appear to have a significant impact on the $\mathrm{XO}$ share. The impact of the GDP on the $\mathrm{XO}$ share is qualitatively similar to our previous results of our baseline estimation in section 5. On the other hand, the per-capita GDP of destination countries' impact on the $X O$ share depends on the specification. The exchange rate has no significant impact on the share of $\mathrm{XO}$ Cognac.

In columns (4) to (6) we perform several robustness checks. In column (4) we use an alternative source to the containerization dates based on Bernhofen et al. (2016). They cover countries that have containerized up until 1983. ${ }^{44}$ A full list of countries and their containerization dates is provided in the Appendix D. Our results are robust. In columns (5) and (6) we exclude from

\footnotetext{
${ }^{43}$ France's first port was containerized in 1968, therefore we exclude from our panel the 1967 and 1968 Cognac trade data.

${ }^{44}$ The two databases differ in the years of adoption of containerization for almost half of the Cognac importing countries. These differences are probably due to the data sources. Rua (2014) constructs her database based on the: Containerisation International Yearbook, Shipping Statistics Yearbook, Lloyd's Ports of the World. Additional data are collected directly from port websites and port authorities. Bernhofen et al. (2016) mention gathering information scattered in transportation industry journals (p.36).
} 
our panel re-exporting countries and US, Japan and China respectively. Our main finding is unaltered: post-containerization has impacted negatively the shares of higher-quality Cognac, providing further empirical evidence of the validity of the Alchian and Allen conjecture.

Table 4 shows the results of our estimation of equation 3 on the relative price of the higherquality Cognac. The post-containerization (column 1) has a positive impact on the relative price of $\mathrm{XO}$ which is in line with our predictions. Decomposing the After $r_{j t}$ dummy variable, we find that the impact on the relative price is evident starting 5 years after the containerization. This result is unaltered when we control for the per-capita Cognac consumption at destination countries (column 3). Our results regarding the impact of the adoption of containerization on the relative prices of higher quality Cognac are overall in line with our results on the impact on the share of XO Cognac.

Our robustness tests of the price equation shown in columns (4) to (6) confirm our previous findings. Post-containerization has a positive impact on the prices of $\mathrm{XO}$ Cognac starting from 5 years. When we use the Bernhofen et al. (2016) database, the effect is present three years after containerization and onward which confirms our predictions.

In Table E.5 in the Appendix we perform further robustness checks, using the PPML estimation method and find qualitatively similar results.

\section{Conclusion}

Using a unique database of annual Cognac shipments by volume, destination and quality designations, we test empirically the validity of Alchian and Allen's (1964) thesis according to which per-unit transportation costs increase the relative demand for higher-quality goods. We test empirically the impact of trade costs on the share of higher quality $(\mathrm{XO})$ Cognac and its relative price. First we evaluate the impact of trade costs (distance and customs protection) across countries. Second we investigate the effect of the variation in trade costs within countries as per the adoption of containerization. Our results validate the Alchian and Allen effect meaning that per-unit trade costs increase the relative demand of higher quality Cognac.

In the introduction to this paper we stated that Cognac is a luxury product. We show that the Alchian and Allen effect is present even for a luxury product.

An object of our future consideration is obtaining the producing firms' data and analyzing their strategies and the determinants of their export performance. It would allow us to examine if the Alchian and Allen effect is due to cross-firm selection (only firms that produce higher quality goods export to more distant markets) or within-firm selection (firms choose higher quality and more expensive goods when they decide to export to more distant markets). 
Table 1 - OLS Estimation: Share of XO in Total Cognac Exports, 1996-2013

\begin{tabular}{|c|c|c|c|c|c|}
\hline & $\begin{array}{c}\text { (1) } \\
\text { Full panel } \\
\text { of countries }\end{array}$ & $\begin{array}{c}\text { (2) } \\
\text { Full panel } \\
\text { of countries }\end{array}$ & $\begin{array}{c}\text { (3) } \\
\text { Full panel } \\
\text { of countries }\end{array}$ & $\begin{array}{c}(4) \\
\text { W/O. Re-exp. } \\
\text { countries }\end{array}$ & $\begin{array}{c}\text { (5) } \\
\text { W/O. US, } \\
\text { China \& Japan }\end{array}$ \\
\hline In Distance $_{j}$ & $\begin{array}{l}0.05^{* * *} \\
(0.00)\end{array}$ & $\begin{array}{l}0.05^{* * *} \\
(0.00)\end{array}$ & $\begin{array}{l}0.05^{* * *} \\
(0.00)\end{array}$ & $\begin{array}{l}0.04^{* * *} \\
(0.00)\end{array}$ & $\begin{array}{l}0.05^{* * *} \\
(0.00)\end{array}$ \\
\hline In Per-unit Duty ${ }_{j t}$ & & $\begin{array}{l}0.01^{* * *} \\
(0.00)\end{array}$ & $\begin{array}{l}0.01^{* * *} \\
(0.00)\end{array}$ & $\begin{array}{c}0.01^{* * *} \\
(0.00)\end{array}$ & $\begin{array}{l}0.01^{* * *} \\
(0.00)\end{array}$ \\
\hline In Ad valorem Duty D $_{j t}$ & & $\begin{array}{c}0.01 \\
(0.01)\end{array}$ & $\begin{array}{c}0.01 \\
(0.01)\end{array}$ & $\begin{array}{c}0.01 \\
(0.01)\end{array}$ & $\begin{array}{c}0.01 \\
(0.01)\end{array}$ \\
\hline $\ln \mathrm{GDP}_{j t}$ & $\begin{array}{l}-0.00 \\
(0.00)\end{array}$ & $\begin{array}{l}-0.00 \\
(0.00)\end{array}$ & $\begin{array}{l}-0.00 \\
(0.00)\end{array}$ & $\begin{array}{l}-0.00 \\
(0.00)\end{array}$ & $\begin{array}{l}-0.00 \\
(0.00)\end{array}$ \\
\hline In GDP/cap $j t$ & $\begin{array}{l}0.01^{* * *} \\
(0.00)\end{array}$ & $\begin{array}{l}0.01^{* * *} \\
(0.00)\end{array}$ & $\begin{array}{l}0.02^{* * *} \\
(0.00)\end{array}$ & $\begin{array}{c}0.02^{* * *} \\
(0.00)\end{array}$ & $\begin{array}{l}0.03^{* * *} \\
(0.00)\end{array}$ \\
\hline In Exchange rate Et & $\begin{array}{l}0.01^{* * *} \\
(0.00)\end{array}$ & $\begin{array}{l}0.01^{* * *} \\
(0.00)\end{array}$ & $\begin{array}{l}0.01^{* * *} \\
(0.00)\end{array}$ & $\begin{array}{c}0.01^{* * *} \\
(0.00)\end{array}$ & $\begin{array}{c}0.01^{* * *} \\
(0.00)\end{array}$ \\
\hline In Cognac Imports/cap $j t$ & & & $\begin{array}{c}-0.00^{* * *} \\
(0.00)\end{array}$ & $\begin{array}{c}-0.01^{* * *} \\
(0.00)\end{array}$ & $\begin{array}{c}-0.00^{* *} \\
(0.00)\end{array}$ \\
\hline Year FE & Yes & Yes & Yes & Yes & Yes \\
\hline Observations & 1852 & 1668 & 1668 & 1607 & 1615 \\
\hline Adjusted $R^{2}$ & 0.122 & 0.138 & 0.141 & 0.135 & 0.147 \\
\hline
\end{tabular}

Robust standard errors in parentheses. In all columns we exclude "small island" countries.

${ }^{*} p<0.10,{ }^{* *} p<0.05,{ }^{* * *} p<0.01$ 
Table 2 - OLS Estimation: XO Relative Export Price, 1996-2013

\begin{tabular}{lccccc}
\hline \hline & $\begin{array}{c}(1) \\
\text { Full panel } \\
\text { of countries }\end{array}$ & $\begin{array}{c}\text { Full panel } \\
\text { of countries }\end{array}$ & $\begin{array}{c}(2) \\
\text { Full panel } \\
\text { of countries }\end{array}$ & $\begin{array}{c}(4) \\
\text { W/O. Re-exp. } \\
\text { countries }\end{array}$ & $\begin{array}{c}\text { W/O. US, } \\
\text { China \& Japan }\end{array}$ \\
\hline In Distance $j$ & $-0.02^{* * *}$ & $-0.02^{* *}$ & $-0.02^{* * *}$ & $-0.03^{* * *}$ & $-0.02^{* *}$ \\
& $(0.01)$ & $(0.01)$ & $(0.01)$ & $(0.01)$ & $(0.01)$ \\
In Per-unit Duty $j t$ & & $-0.01^{* *}$ & -0.01 & -0.00 & $-0.01^{*}$ \\
& & $(0.00)$ & $(0.00)$ & $(0.00)$ & $(0.00)$ \\
In Ad valorem Duty $j t$ & & -0.01 & -0.01 & -0.01 & -0.02 \\
& & $(0.01)$ & $(0.01)$ & $(0.01)$ & $(0.01)$ \\
In GDP ${ }_{j t}$ & $-0.01^{* * *}$ & $-0.01^{* * *}$ & $-0.02^{* * *}$ & $-0.02^{* * *}$ & $-0.01^{*}$ \\
& $(0.00)$ & $(0.00)$ & $(0.00)$ & $(0.00)$ & $(0.00)$ \\
In GDP/cap $j t$ & -0.01 & $-0.01^{*}$ & $0.02^{* *}$ & $0.02^{* *}$ & 0.01 \\
& $(0.01)$ & $(0.01)$ & $(0.01)$ & $(0.01)$ & $(0.01)$ \\
In Exchange rate ${ }_{j t}$ & $-0.01^{* * *}$ & $-0.01^{* * *}$ & $-0.01^{* * *}$ & $-0.01^{* * *}$ & $-0.01^{* * *}$ \\
& $(0.00)$ & $(0.00)$ & $(0.00)$ & $(0.00)$ & $(0.00)$ \\
In Cognac Imports/cap & & & $-0.02^{* * *}$ & $-0.02^{* * *}$ & $-0.02^{* * *}$ \\
& & & $(0.00)$ & $(0.00)$ & $(0.00)$ \\
\hline Year FE & & Yes & Yes & Yes & Yes \\
\hline Observations & & 1668 & 1668 & 1607 & 1615 \\
Adjusted $R^{2}$ & 1852 & 0.113 & 0.127 & 0.123 & 0.115 \\
\hline \hline
\end{tabular}

Robust standard errors in parentheses. In all columns we exclude "small island" countries.

${ }^{*} p<0.10,{ }^{* *} p<0.05,{ }^{* * *} p<0.01$ 


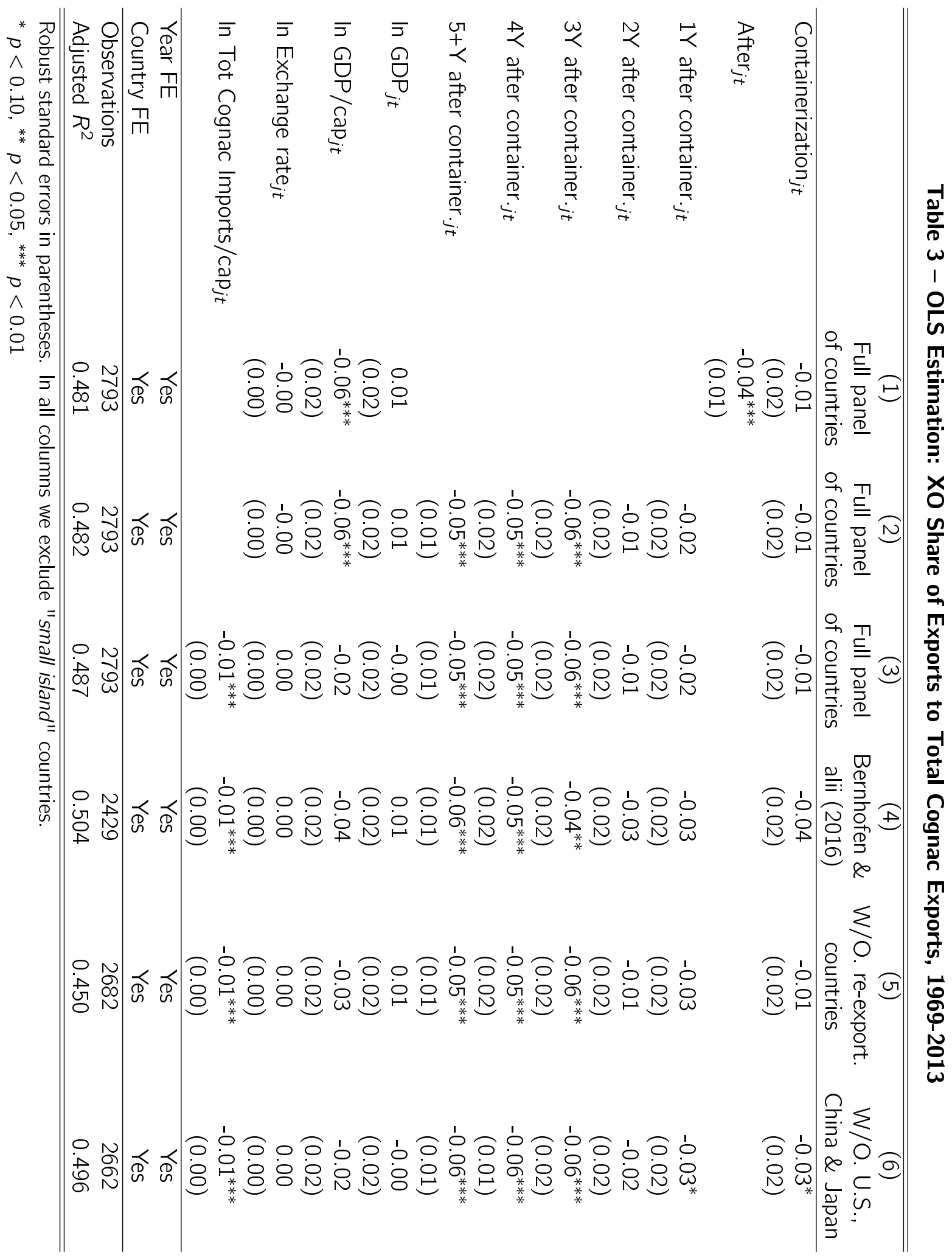




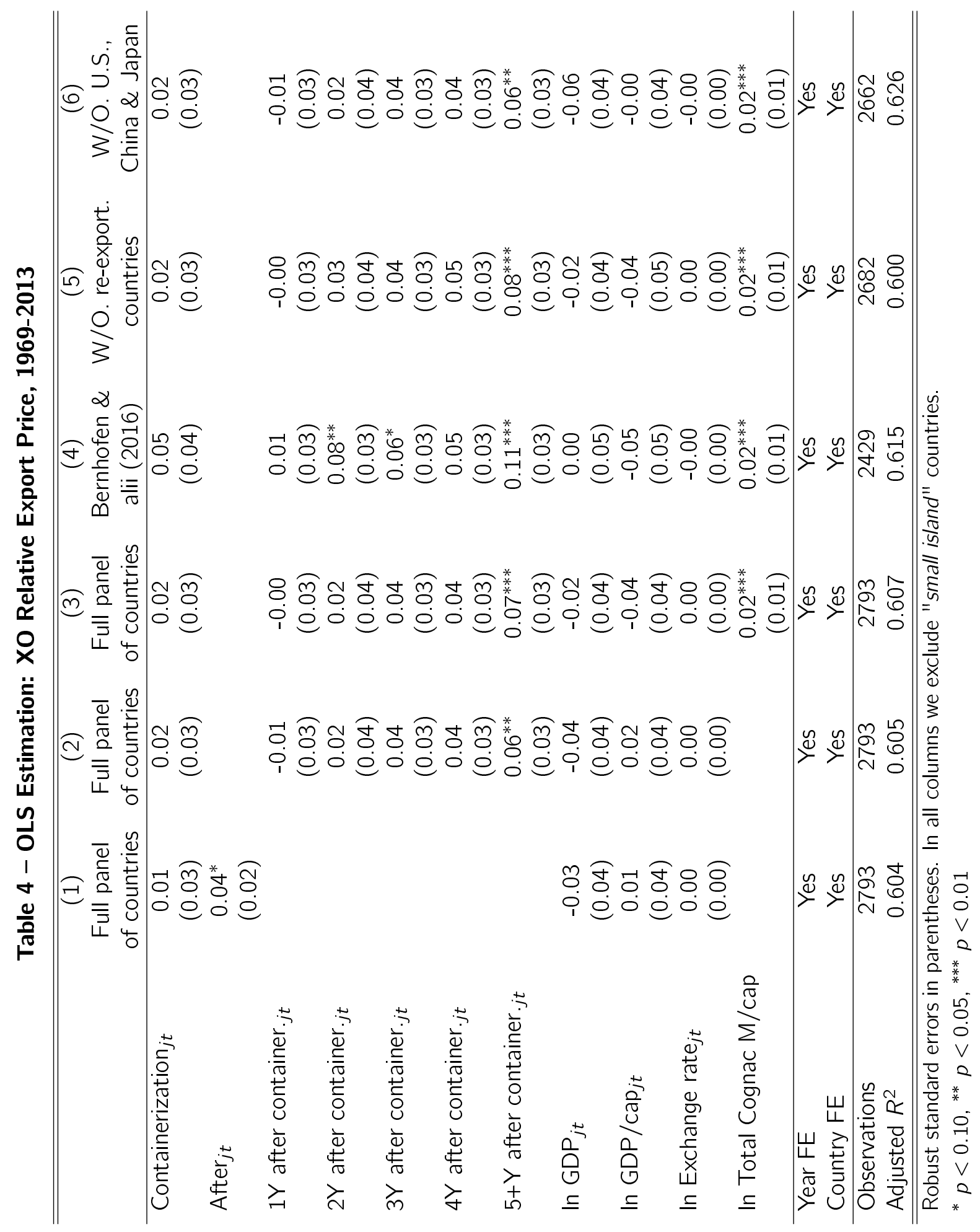




\section{References}

Alchian, A. A. and Allen, W. (1964). University Economics: Elements of Inquiry. Belmont, CA: Wadsworth Publishing Company.

Anderson, J.E. and van Wincoop, E. (2004). Trade Costs. Journal of Economic Literature, 42(3), 691751.

Baldwin, R. (1985). The Political Economy of U.S. Import Policy. Cambridge, MASS.: MIT Press.

Baldwin, R. and Harrigan, J. (2011). Zeros, Quality, and Space: Trade Theory and Trade Evidence. American Economic Journal: Microeconomics, 3(2), 60-88.

Barzel Y. (1976). An Alternative Approach to the Analysis of Taxation. Journal of Political Economy, 84, 1177-1197.

Bastos, P. and Silva, J. (2010). The Quality of a Firm's Exports: Where You Export to Matters. Journal of International Economics, 82(2): 99-111.

Bauman, Y. (2004). Shipping the Good Apples Out: A New Perspective. Economic Inquiry, 42(3), 534-536.

Bernhofen, D., El-Sahli, Z., and Kneller, R. (2016). Estimating the Effects of the Container Revolution on World Trade. Journal of International Economics, 98, 36-50.

Bertonazzi, E., Maloney, M., and McCormick, R. (1993). Some Evidence on the Alchian and Allen Theorem: The Third Law of Demand? Economic Inquiry, 31(July), 383-393.

Bouët, A., Emlinger, Ch., and Lamani, V. (2017). What Determines Exports of Luxury Products? The Case of Cognac. Journal of Wine Economics, 12(1), 1-22.

Borcherding, T. E., and Silberberg, E. (1978). Shipping the Good Apples Out: The Alchian and Allen Theorem Reconsidered. Journal of Political Economy, 86(1), 131-138.

Crozet, M., Head, K., and Mayer, Th. (2012). Quality Sorting and Trade: Firm-level Evidence for French Wine. Review of Economic Studies, 79(2), 609-644.

Falvey, R.E., (1979). The Composition of Trade Within Import-Restricted Product Categories. Journal of Political Economy, 87(5), 1105-1114.

Fogarty, J. (2010). The Demand for Beer, Wine and Spirits: A Survey of the Literature. Journal of Economic Surveys, 24(3), 428-478.

Fontagné, L. and Hatte, S. (2013). European High-End Products in International Competition. Paris School of Economics Working Paper No. 37.

Gould, J.P., and Segall, J. (1969). The Substitution Effects of Transportation Costs. Journal of Political Economy, 77, 130-137. 
Hallak, J.C. (2006). Product Quality and the Direction of Trade. Journal of International Economics, 68(1), 238-265.

Hallak, J. C. and Sivadasan, J. (2009). Firms' Exporting Behavior under Quality Constraints, NBER Working Papers No. 14928.

Hummels, D. and Klenow, P.J. (2005). The Variety and Quality of a Nation's Exports. American Economic Review, 95(3), 704-723.

Hummels, D. and Skiba, A. (2004). Shipping the Good Apples Out? An Empirical Confirmation of the Alchian-Allen Conjecture. Journal of Political Economy, 112(6), 1384-1402.

Hummels, D. (2007). Transportation Costs and International Trade in the Second Era of Globalization. Journal of Economic Perspectives, 21(3), 131-154.

Irarrazabal, A., Moxnes, A. and Opromolla, L. D. (2015). The tip of the Iceberg: A Quantitative Framework for Estimating Trade Costs. Review of Economics and Statistics, 97(4), 777-792.

Jorgensen, J. G. and Schröder P. J. H. (2005). Welfare-ranking Ad Valorem and Specific Tariffs under Monopolistic Competition. Canadian Journal of Economics, 38(1), 228-241.

Kaempfer, W. H., and Brastow, R. T. (1985). The Effect of Unit Fees on the Consumption of Quality. Economic Inquiry, XXIII(April), 341-348.

Khandelwal, A.K., Schott, P. K., and Wei, Sh-J. (2013). Trade Liberalization and Embedded Institutional Reform: Evidence from Chinese Exporters. American Econonomic Review, 103(6), 2169-2195.

Krugman, P.R., (1979). Increasing Returns, Monopolistic Competition and International Trade. Journal of International Economics, 9(4), 369-379.

Lancaster, K., (1980). Intra-Industry Trade under Perfect Monopolistic Competition. Journal of International Economics, 10(2), 151-176.

Lawson, R. and Raymer, L. (2006). Testing the Alchian-Allen Theorem: A study of Consumer Behavior in the Gasoline Market. Economics Bulletin, 35(4), 1-6.

Levinson, M. (2006). The Box: How the Shipping Container Made the World Smaller and the World Economy Bigger. Princeton University Press.

Linder, S. (1961). An Essay on Trade and Transformation. Almqvist \& Wiksell, Stockholm.

Liu, L. (2010). The Alchian-Allen Theorem and the Law of Relative Demand: The Case of Multiple Differentiable Brands. Mathematical Social Sciences, 61, 52-57.

Manova, K. and Zhang, Z. (2009). Export Prices across Firms and Destinations. The Quaterly Journal of Economics, 127(1), 379-436.

Martin, J. (2012). Markups, Quality, and Transport Costs. European Economic Review, 56(4), 777-791. 
Martin, J., and Mayneris, F. (2016). High-End Variety Exporters Defying Gravity: Micro Facts and Aggregate Implications. Journal of International Economics, 96(1), 55-71.

Mayer, W. (1984). Endogenous Tariff Formation. American Economic Review, 74(5), 970-985.

McKinsey. (1972). Containerization: A 5-year Balance Sheet.

Nesbit, T. (2007). Excise Taxation and Product Quality: The Gasoline Market. Economic Issues, 12(2), $1-14$.

Razzolini, L., Shughart II, W. F., and Tollison, R. D. (2003). On The Third Law Of Demand. Economic Inquiry, 41(2), 292-298.

Rua, G. (2014). Diffusion of Containerization. Finance and Economics Discussion Series Staff Working Paper 2014-88, Federal Reserve Board, Washington, DC.

Saito, T., (2006). Shipping the Good Apples Out: Alchian-Allen Theorem of Various Qualities. MPRA Working Paper N.901.

Schott, P. K. (2004). Across-product Versus Within-product Specialization in International Trade. The Quarterly Journal of Economics, 119(2), 646-678.

Schott P. K. (2008). The Relative Sophistication of Chinese Exports. Economic Policy, 23(53), 5-49.

Sorensen, A. (2014). Additive versus Multiplicative Trade Costs and the Gains from Trade Liberalizations. Canadian Journal of Economics, 47(3), 1032-1046.

Umbeck, J. (1980). Shipping the Good Apples Out: Some Ambiguities in the Interpretation of "Fixed Charge." Journal of Political Economy, 88(1).

Verhoogen, E. A. (2008). Trade, Quality Upgrading, and Wage Inequality in the Mexican Manufacturing Sector. The Quarterly Journal of Economics, 123(2), 489-530. 


\section{Appendix}

\section{A. General Framework: Mathematical Proof}

Proof of equation 1 :

$$
\frac{\partial\left(X_{j H} / X_{j L}\right)}{\partial t_{j}}=\frac{\frac{\partial X_{j H}}{\partial t_{j}} X_{j L}-X_{j H} \frac{\partial X_{j L}}{\partial t_{j}}}{X_{j L}^{2}}
$$

From the chain rule we have:

$$
\frac{\partial X_{j k}}{\partial t_{j}}=\frac{\partial X_{j k}}{\partial p_{j H}}+\frac{\partial X_{j k}}{\partial p_{j L}} \quad k=H, L
$$

Substituting into (4):

$$
\frac{\partial\left(X_{j H} / X_{j L}\right)}{\partial t_{j}}=\frac{\left(\frac{\partial X_{j H}}{\partial p_{j H}}+\frac{\partial X_{j H}}{\partial p_{j L}}\right) X_{j L}-X_{j H}\left(\frac{\partial X_{j L}}{\partial p_{j H}}+\frac{\partial X_{j L}}{\partial p_{j L}}\right)}{X_{j L}^{2}}
$$

$<=>$

$$
\frac{\partial\left(X_{j H} / X_{j L}\right)}{\partial t_{j}}=\frac{\left(\epsilon_{H H} \frac{X_{j H}}{p_{j H}}+\epsilon_{H L} \frac{X_{j H}}{p_{j L}}\right) X_{j L}-X_{j H}\left(\epsilon_{L H} \frac{X_{j L}}{p_{j H}}+\epsilon_{L L} \frac{X_{j L}}{p_{j L}}\right)}{X_{j L}^{2}} \text {, with } \epsilon_{k m}=\frac{\partial X_{j k}}{\partial p_{j k}} \frac{p_{j k}}{X_{j k}}
$$

$<=>$

$$
\frac{\partial\left(X_{j H} / X_{j L}\right)}{\partial t_{j}}=\frac{X_{j H}}{X_{j L}}\left(\frac{\epsilon_{H H}}{p_{j H}}+\frac{\epsilon_{H L}}{p_{j L}}-\frac{\epsilon_{L H}}{p_{j H}}-\frac{\epsilon_{L L}}{p_{j L}}\right)
$$

From Hick's third law: $\sum_{j=1}^{2} \epsilon_{i j}=0, i=1$, 2. Substituting $\epsilon_{L L}$ for $\epsilon_{H H}$ and $\epsilon_{H L}$ into (5), we have:

$$
\frac{\partial\left(X_{j H} / X_{j L}\right)}{\partial t_{j}}=\frac{X_{j H}}{X_{j L}}\left(\frac{-\epsilon_{H L}}{p_{j H}}+\frac{\epsilon_{H L}}{p_{j L}}+\frac{\epsilon_{L L}}{p_{j H}}-\frac{\epsilon_{L L}}{p_{j L}}\right)
$$

$<=>$

$$
\frac{\partial\left(X_{j H} / X_{j L}\right)}{\partial t_{j}}=\frac{X_{j H}}{X_{j L}}\left(\frac{1}{p_{j L}}-\frac{1}{p_{j H}}\right)\left(\epsilon_{H L}-\epsilon_{L L}\right)
$$

The term $\frac{1}{p_{j L}}-\frac{1}{p_{j H}}$ in $(6)$ is positive because $p_{i H}>p_{i L}$. As long as $X_{j H}$ and $X_{j H}$ are close substitutes, $\epsilon_{H L}>0$. Given that the own price-elasticity $\epsilon_{L L}<0$, the term $\epsilon_{H L}-\epsilon_{L L}>0$, therefore $\frac{\partial\left(X_{j H} / X_{j L}\right)}{\partial t_{j}}>0$, verifying the Alchian and Allen effect. 


\section{B. Stylized facts: Main markets}

Table B.1 - Descriptive Statistics - share of XO in imports of main markets

\begin{tabular}{|l|cc|ccccc|}
\hline \hline & $\begin{array}{c}\text { Share in } \\
\text { total exports }\end{array}$ & $\begin{array}{c}\text { Share in } \\
\text { XO exports }\end{array}$ & Nb. Obs. & mean & sd & min & max \\
\hline Total & - & - & 2842 & 13.64 & 14.47 & 0.01 & 95.01 \\
\hline USA & 32.20 & 8.80 & 22 & 3.37 & 1.26 & 1.89 & 7.22 \\
Singapore & 17.62 & 27.54 & 22 & 27.48 & 6.36 & 18.98 & 39.08 \\
China & 12.66 & 28.24 & 22 & 34.94 & 15.69 & 10.16 & 73.42 \\
UK & 6.43 & 0.71 & 22 & 1.53 & 0.18 & 1.22 & 2.00 \\
Germany & 3.73 & 2.54 & 22 & 5.63 & 2.14 & 2.20 & 9.50 \\
Hong Kong & 2.93 & 9.93 & 22 & 38.80 & 9.19 & 17.93 & 53.78 \\
Netherlands & 2.27 & 1.11 & 22 & 4.73 & 1.87 & 1.89 & 7.92 \\
Norway & 1.73 & 2.75 & 22 & 18.12 & 7.93 & 2.13 & 26.05 \\
Finland & 1.42 & 1.11 & 22 & 11.21 & 4.44 & 6.16 & 23.68 \\
Russia & 1.33 & 0.94 & 22 & 12.25 & 4.56 & 2.43 & 22.23 \\
Latvia & 1.30 & 1.02 & 21 & 11.42 & 5.71 & 1.15 & 27.46 \\
Malaysia & 1.04 & 3.72 & 22 & 29.50 & 12.33 & 12.98 & 49.93 \\
Nigeria & 1.03 & 0.19 & 22 & 1.96 & 0.95 & 0.38 & 4.36 \\
Ireland & 0.93 & 0.01 & 22 & 0.25 & 0.08 & 0.11 & 0.44 \\
Canada & 0.89 & 0.43 & 22 & 6.68 & 1.21 & 3.66 & 8.46 \\
\hline \hline
\end{tabular}


C. Distance, Tariffs and Quality Mix: Additional Test

Table C.2 - Alternative Estimation Method: PPML, 1996-2013

\begin{tabular}{|c|c|c|}
\hline & $\begin{array}{l}(1) \\
\text { XO } \text { Share }_{j} t\end{array}$ & $\begin{array}{c}(2) \\
X O U V_{j} t\end{array}$ \\
\hline In Distance $_{j}$ & $\begin{array}{l}0.37^{* * *} \\
(0.02)\end{array}$ & $\begin{array}{l}0.37^{* * *} \\
(0.02)\end{array}$ \\
\hline In Per-unit Duty $j t$ & $\begin{array}{c}0.04^{* * *} \\
(0.01)\end{array}$ & $\begin{array}{l}0.04^{* * *} \\
(0.01)\end{array}$ \\
\hline In Ad valorem Duty $_{j t}$ & $\begin{array}{c}0.07 \\
(0.05)\end{array}$ & $\begin{array}{c}0.07 \\
(0.05)\end{array}$ \\
\hline $\ln \mathrm{GDP}_{j t}$ & $\begin{array}{l}-0.02^{*} \\
(0.01)\end{array}$ & $\begin{array}{l}-0.02^{*} \\
(0.01)\end{array}$ \\
\hline $\ln \mathrm{GDP} / \mathrm{cap}_{j t}$ & $\begin{array}{l}0.14^{* * *} \\
(0.03)\end{array}$ & $\begin{array}{l}0.14^{* * *} \\
(0.03)\end{array}$ \\
\hline In Exchange rate ${ }_{j t}$ & $\begin{array}{l}0.06^{* * *} \\
(0.01)\end{array}$ & $\begin{array}{c}0.06^{* * *} \\
(0.01)\end{array}$ \\
\hline In Cognac Imports/cap ${ }_{j t}$ & $\begin{array}{c}-0.03^{* *} \\
(0.01)\end{array}$ & $\begin{array}{c}-0.03^{* *} \\
(0.01)\end{array}$ \\
\hline Year FE & Yes & Yes \\
\hline $\begin{array}{l}\text { Observations } \\
\text { Adjusted } R^{2}\end{array}$ & 1668 & 1668 \\
\hline
\end{tabular}

Robust standard errors in parentheses.

In In both columns we exclude "small island" countries.

${ }^{*} p<0.10,{ }^{* *} p<0.05,{ }^{* * *} p<0.01$ 


\section{Containerization: Databases}


Table D.3 - Adoption of containerization (i.e. first port containerized) by Cognac importing countries

\begin{tabular}{|c|c|c|}
\hline Country Name & $\begin{array}{l}\text { Containerization Date } \\
\text { (Rua, 2014) }\end{array}$ & $\begin{array}{l}\text { Containerization Date } \\
\text { (Bernhofen et al., 2016) }\end{array}$ \\
\hline ALGERIA & 1979 & 1979 \\
\hline ANGOLA & 1979 & 1979 \\
\hline ARGENTINA & 1977 & 1976 \\
\hline ARUBA & 1976 & \\
\hline AUSTRALIA (and PAPUA NEW GUINEA) & 1964 & 1968 \\
\hline AUSTRIA & 1982 & $1982(*)$ \\
\hline BAHAMAS & 1972 & 1973 \\
\hline BAHRAIN & 1977 & 1977 \\
\hline BANGLADESH & 1981 & 1981 \\
\hline BELGIUM (and LUXEMBOURG) & 1966 & 1968 \\
\hline BELIZE & 1981 & 1981 \\
\hline BENIN & 1976 & 1976 \\
\hline BERMUDA & 1983 & 1983 \\
\hline BRAZIL & 1971 & 1973 \\
\hline BULGARIA & 1972 & $1972(\mathrm{R})$ \\
\hline CAMBODIA & 2003 & \\
\hline CAMEROON & 1973 & 1974 \\
\hline CANADA & 1968 & 1968 \\
\hline CAYMAN ISLANDS & 1998 & \\
\hline CHILE & 1973 & 1974 \\
\hline CHINA & 1979 & 1979 \\
\hline COLOMBIA & 1971 & $1974(\mathrm{R})$ \\
\hline CONGO & 1979 & 1979 \\
\hline CONGO, DEMOCRATIC REPUBLIC OF THE & 1981 & 1981 \\
\hline COSTA RICA & 1980 & 1981 \\
\hline COTE D'IVOIRE & 1970 & 1971 \\
\hline CUBA & 2000 & \\
\hline CYPRUS & 1977 & 1977 \\
\hline DENMARK & 1969 & 1968 \\
\hline DJIBOUTI & 1979 & 1979 \\
\hline DOMINICAN REPUBLIC & 1976 & 1981 \\
\hline ECUADOR & 1970 & 1978 \\
\hline EGYPT & 1978 & 1978 \\
\hline EL SALVADOR & 1978 & 1979 \\
\hline EX-CZECHOSLOVAKIA & 1979 & $1979\left(^{*}\right)$ \\
\hline EX-YUGOSLAVIA & 1970 & $1970(*)$ \\
\hline FINLAND & 1970 & 1969 \\
\hline FORMER URSS & 1971 & $1970(\mathrm{R})$ \\
\hline FRENCH POLYNESIA & 1978 & \\
\hline GAMBIA & 1982 & 1982 \\
\hline GERMANY & 1968 & 1966 \\
\hline GHANA & 1978 & 1977 \\
\hline GIBRALTAR & 1978 & 1978 \\
\hline GREECE & 1971 & 1970 \\
\hline GUATEMALA & 1976 & 1980 \\
\hline GUINEA & 1983 & 1983 \\
\hline HAITI & 1976 & 1978 \\
\hline HONDURAS & 1975 & 1975 \\
\hline HONG KONG & 1970 & 1970 \\
\hline HUNGARY & 1969 & $1969(*)$ \\
\hline ICELAND & 1973 & 1973 \\
\hline INDIA & 1971 & $1971(*)$ \\
\hline INDONESIA & 1975 & 1975 \\
\hline IRAN, ISLAMIC REPUBLIC OF & 1977 & 1977 \\
\hline IRAQ & 1977 & 1978 \\
\hline IRELAND & 1967 & $1968(\mathrm{R})$ \\
\hline ISRAEL & 1970 & 1970 \\
\hline ITALY & 1968 & 1968 \\
\hline
\end{tabular}

Bernhofen et al. (2016) database reports the dates of containerization by port or rail, whichever took place first.

Countries marked with $(\mathrm{R})$ containerized by rail first and are dropped from the estimations. Countries marked with $(*)$ also containerized by rail first. Because the adoption occurred before port containerization comparing it to Rua's (2014) data, we substitute the latter to the former date. 
Table D.4 - Adoption of containerization (i.e. first port containerized) by Cognac importing countries (Continued)

\begin{tabular}{|c|c|c|}
\hline Country Name & $\begin{array}{c}\text { Containerization Date } \\
\text { (Rua, 2014) }\end{array}$ & $\begin{array}{l}\text { Containerization Date } \\
\text { (Bernhofen et al., 2016) }\end{array}$ \\
\hline JAMAICA & 1969 & 1973 \\
\hline JAPAN & 1968 & 1969 \\
\hline JORDAN & 1976 & 1977 \\
\hline KENYA & 1975 & 1976 \\
\hline KOREA, REPUBLIC OF & 1975 & 1975 \\
\hline KUWAIT & 1977 & 1977 \\
\hline LEBANON & 1977 & 1977 \\
\hline LIBERIA & 1980 & 1980 \\
\hline LIBYA & 1979 & 1980 \\
\hline MADAGASCAR & 1980 & 1980 \\
\hline MALTA & 1979 & 1983 \\
\hline MAURITANIA & 1982 & 1982 \\
\hline MEXICO & 1976 & 1976 \\
\hline MOROCCO & 1977 & 1977 \\
\hline MOZAMBIQUE & 1975 & 1978 \\
\hline MYANMAR & 1982 & 1983 \\
\hline NETHERLANDS & 1966 & 1966 \\
\hline NETHERLANDS ANTILLES & 1979 & 1979 \\
\hline NEW CALEDONIA & 1981 & 1976 \\
\hline NEW ZEALAND & 1967 & 1971 \\
\hline NICARAGUA & 1977 & 1979 \\
\hline NIGERIA & 1967 & 1974 \\
\hline NORWAY & 1968 & $1969(\mathrm{R})$ \\
\hline PAKISTAN & 1980 & 1979 \\
\hline PANAMA & 1976 & $1976(*)$ \\
\hline PERU & 1969 & 1975 \\
\hline PHILIPPINES & 1971 & 1971 \\
\hline POLAND & 1970 & 1971 \\
\hline PORTUGAL & 1970 & 1969 \\
\hline QATAR & 1979 & 1979 \\
\hline ROMANIA & 1981 & $1981(*)$ \\
\hline SAMOA & 1981 & 1978 \\
\hline SAUDI ARABIA & 1976 & 1976 \\
\hline SENEGAL & 1985 & \\
\hline SIERRA LEONE & 1978 & 1978 \\
\hline SINGAPOURE & 1969 & 1970 \\
\hline SOUTH AFRICA & 1971 & 1974 \\
\hline SPAIN & 1967 & 1968 (R) \\
\hline SUDAN & 1979 & 1980 \\
\hline SWEDEN & 1968 & $1968(\mathrm{R})$ \\
\hline SWITZERLAND & 1968 & $1968(R)$ \\
\hline SYRIAN ARAB REPUBLIC & 1979 & 1979 \\
\hline TAIWAN, PROVINCE OF CHINA & 1969 & 1968 \\
\hline TANZANIA, UNITED REPUBLIC OF & 1975 & 1978 \\
\hline THAILAND & 1975 & 1975 \\
\hline TOGO & 1981 & 1981 \\
\hline TRINIDAD AND TOBAGO & 1973 & 1971 \\
\hline TUNISIA & 1981 & 1981 \\
\hline TURKEY & 1981 & 1981 \\
\hline UNITED KINGDOM & 1966 & 1966 \\
\hline UNITED STATES & 1956 & 1966 \\
\hline URUGUAY & 1980 & 1980 \\
\hline VANUATU & 1978 & \\
\hline VENEZUELA, BOLIVARIAN REPUBLIC OF & 1981 & 1981 \\
\hline VIET NAM & 2000 & \\
\hline YEMEN & 1978 & \\
\hline
\end{tabular}

Bernhofen et al. (2016) database reports the dates of containerization by port or rail, whichever took place first.

Countries marked with $(\mathrm{R})$ containerized by rail first and are dropped from the estimations. Countries marked with $(*)$ also containerized by rail first. Because the adoption occurred before port containerization comparing it to Rua's (2014) data, we substitute the latter to the former date. 
E. Containerization and Quality Mix: Additional Test

Table E.5 - Alternative Estimation Method: PPML, 1969-2013

\begin{tabular}{|c|c|c|}
\hline & $\begin{array}{l}(1) \\
\text { XO } \text { Share }_{j} t\end{array}$ & 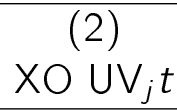 \\
\hline Containerization $_{j t}$ & $\begin{array}{l}-0.14 \\
(0.13)\end{array}$ & $\begin{array}{c}0.04^{*} \\
(0.02)\end{array}$ \\
\hline $1 Y$ after container. $\cdot j t$ & $\begin{array}{l}-0.16 \\
(0.11)\end{array}$ & $\begin{array}{c}0.01 \\
(0.02)\end{array}$ \\
\hline $2 Y$ after container ${ }_{\cdot j t}$ & $\begin{array}{l}-0.11 \\
(0.11)\end{array}$ & $\begin{array}{l}0.06^{* *} \\
(0.02)\end{array}$ \\
\hline $3 Y$ after container. ${ }_{-j t}$ & $\begin{array}{c}-0.22^{* *} \\
(0.10)\end{array}$ & $\begin{array}{l}0.04^{*} \\
(0.02)\end{array}$ \\
\hline $4 Y$ after container. ${ }^{-j t}$ & $\begin{array}{c}-0.25^{* * *} \\
(0.09)\end{array}$ & $\begin{array}{c}0.03 \\
(0.02)\end{array}$ \\
\hline $5+Y$ after container. $\cdot j t$ & $\begin{array}{c}-0.33^{* * *} \\
(0.08)\end{array}$ & $\begin{array}{l}0.08^{* * *} \\
(0.02)\end{array}$ \\
\hline $\ln \mathrm{GDP}_{j t}$ & $\begin{array}{l}0.22^{*} \\
(0.13)\end{array}$ & $\begin{array}{l}-0.01 \\
(0.03)\end{array}$ \\
\hline $\ln \mathrm{GDP} / \operatorname{cap}_{j t}$ & $\begin{array}{l}-0.16 \\
(0.16)\end{array}$ & $\begin{array}{l}-0.01 \\
(0.03)\end{array}$ \\
\hline In Exchange rate ${ }_{j t}$ & $\begin{array}{c}0.00 \\
(0.01)\end{array}$ & $\begin{array}{l}-0.00 \\
(0.00)\end{array}$ \\
\hline In Tot Cognac Imports/cap ${ }_{j t}$ & $\begin{array}{c}-0.06^{* * *} \\
(0.02) \\
\end{array}$ & $\begin{array}{l}0.01^{* * *} \\
(0.00)\end{array}$ \\
\hline Year FE & Yes & Yes \\
\hline Country FE & Yes & Yes \\
\hline $\begin{array}{l}\text { Observations } \\
\text { Adjusted } R^{2}\end{array}$ & 2429 & 2429 \\
\hline $\begin{array}{l}\text { Robust standard errors in parenthe } \\
\text { In both columns we exclude "smal } \\
{ }^{*} p<0.10,{ }^{* *} p<0.05,{ }^{* * *} p<0 .\end{array}$ & and" countrie & \\
\hline
\end{tabular}

